\title{
Preliminary conceptual model of the Cerro Blanco caldera-hosted geothermal system (Southern Puna, Argentina): Inferences from geochemical investigations
}

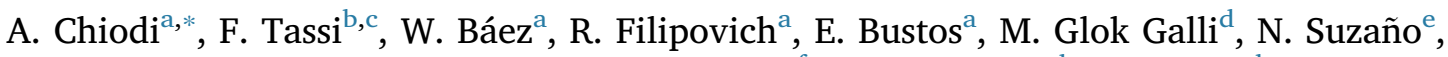 \\ Ma. F. Ahumada ${ }^{\mathrm{a}}$, J.G. Viramonte ${ }^{\mathrm{a}}$, G. Giordano ${ }^{\mathrm{f}, \mathrm{g}}$, G. Pecoraino ${ }^{\mathrm{h}}$, O. Vaselli ${ }^{\mathrm{b}, \mathrm{c}}$ \\ ${ }^{\mathrm{a}}$ Instituto de Bio y Geociencias del NOA (IBIGEO, UNSa-CONICET), Av. 9 de Julio14, A4405BBA Salta, Argentina \\ ${ }^{\mathrm{b}}$ Department of Earth Sciences, University of Florence, Via La Pira 4, 50121 Florence, Italy \\ ${ }^{\mathrm{c}}$ CNR-IGG Institute of Geosciences and Earth Resources, Via La Pira 4, 50121 Florence, Italy \\ ${ }^{\mathrm{d}}$ Centro de Investigaciones en Física e Ingeniería del Centro de la Provincia de Buenos Aires (CIFICEN), Pinto 399, 7000, Buenos Aires, Argentina \\ ${ }^{\mathrm{e}}$ Universidad Nacional de Jujuy, Argentina \\ ${ }^{\mathrm{f}}$ Department of Sciences, University Roma Tre, 00146 Rome, Italy \\ ${ }^{\mathrm{g}}$ CNR-IDPA Institute for Dynamics of Environmental Processes, Via M. Bianco, 20131 Milan, Italy \\ ${ }^{\mathrm{h}}$ Istituto Nazionale di Geofisica e Vulcanologia (INGV), Sezione di Palermo, Via Ugo La Malfa 153, 90146, Palermo, Italy
}

\section{A R T I C L E I N F O}

\section{Keywords:}

Hydrothermal system

Fluid geochemistry

Geothermal prospection

Quaternary caldera

Northwestern Argentina

\begin{abstract}
A B S T R A C T
The Cerro Blanco Caldera ( $\mathrm{CBC}$ ) is the youngest collapse caldera system in the Southern Central Andes (Southern Puna, Argentina). The $\mathrm{CBC}$ is subsiding with at an average velocity of $0.87 \mathrm{~cm} /$ year and hosts an active geothermal system. A geochemical characterization of emitted fluids was carried out based on the chemical and isotopic compositions of fumaroles, and thermal and cold springs discharged in this volcanic area with the aim of constructing the first hydrogeochemical conceptual model and preliminary estimate the geothermal potential. The main hydrothermal reservoir, likely hosted within the pre-caldera basement rocks, has a $\mathrm{Na}^{+}-\mathrm{Cl}^{-}\left(\mathrm{HCO}_{3}\right)$ composition with estimated temperatures $\geq 135^{\circ} \mathrm{C}$. The unconsolidated, fine-grained Cerro Blanco ignimbrite likely acts as the cap-rock of the hydrothermal system. The presence of phreatic eruption breccias in the surrounding area of the geothermal fumaroles supports the effectiveness of the pyroclastic deposit as sealing rocks. The isotopic data of water $\left(\delta^{18} \mathrm{O}\right.$ and $\left.\delta \mathrm{D}\right)$ indicate a meteoric recharge of the hydrothermal reservoir, suggesting as recharge areas the sectors surrounding the $\mathrm{CBC}$, mainly towards the $\mathrm{W}$ and $\mathrm{NW}$ where large outcrops of the pre-caldera basement exist. A fault-controlled hydraulic connection between the hot springs and the hydrothermal reservoir is proposed for the Los Hornitos area. The fumaroles show the typical compositional features of hydrothermal fluids, being dominated by water vapor with significant concentrations of $\mathrm{H}_{2} \mathrm{~S}, \mathrm{CH}_{4}$ and $\mathrm{H}_{2}$. Considering the high geothermal gradient of this area $\left(\sim 104^{\circ} \mathrm{C} / \mathrm{km}\right)$ and the relatively high fraction of mantle $\mathrm{He}(\sim 39 \%)$ calculated on the basis of the measured R/Ra values, the hydrothermal aquifer likely receives inputs of magmatic fluids from the degassing magma chamber. The preliminary geothermal potential at CBC was evaluated with the Volume Method, calculating up to $E=11.4 * 10^{18} \mathrm{~J}$. Both the scarce presence of superficial thermal manifestations and the occurrence of an efficient cap-rock likely contribute to minimize the loss of thermal energy from the reservoir. The results here presented constitute the necessary base of knowledge for further accurate assessment of the geothermal potential and ultimately the implementation of the geothermal resource as a viable energy alternative for small localities or mining facilities isolated from the National Interconnected System due to their remote localization.
\end{abstract}

\section{Introduction}

Andean South American countries constitute promising sites for geothermal exploration due to their position upon the Pacific Ring of
Fire, where magmatic and tectonic features favor the development of geothermal systems. Despite the proven existence of this resource in South America, only one geothermal plant is currently producing electrical energy. This is the recently inaugurated (September 2017)

\footnotetext{
* Corresponding author.

E-mail address: a.chiodi@conicet.gov.ar (A. Chiodi).
} 


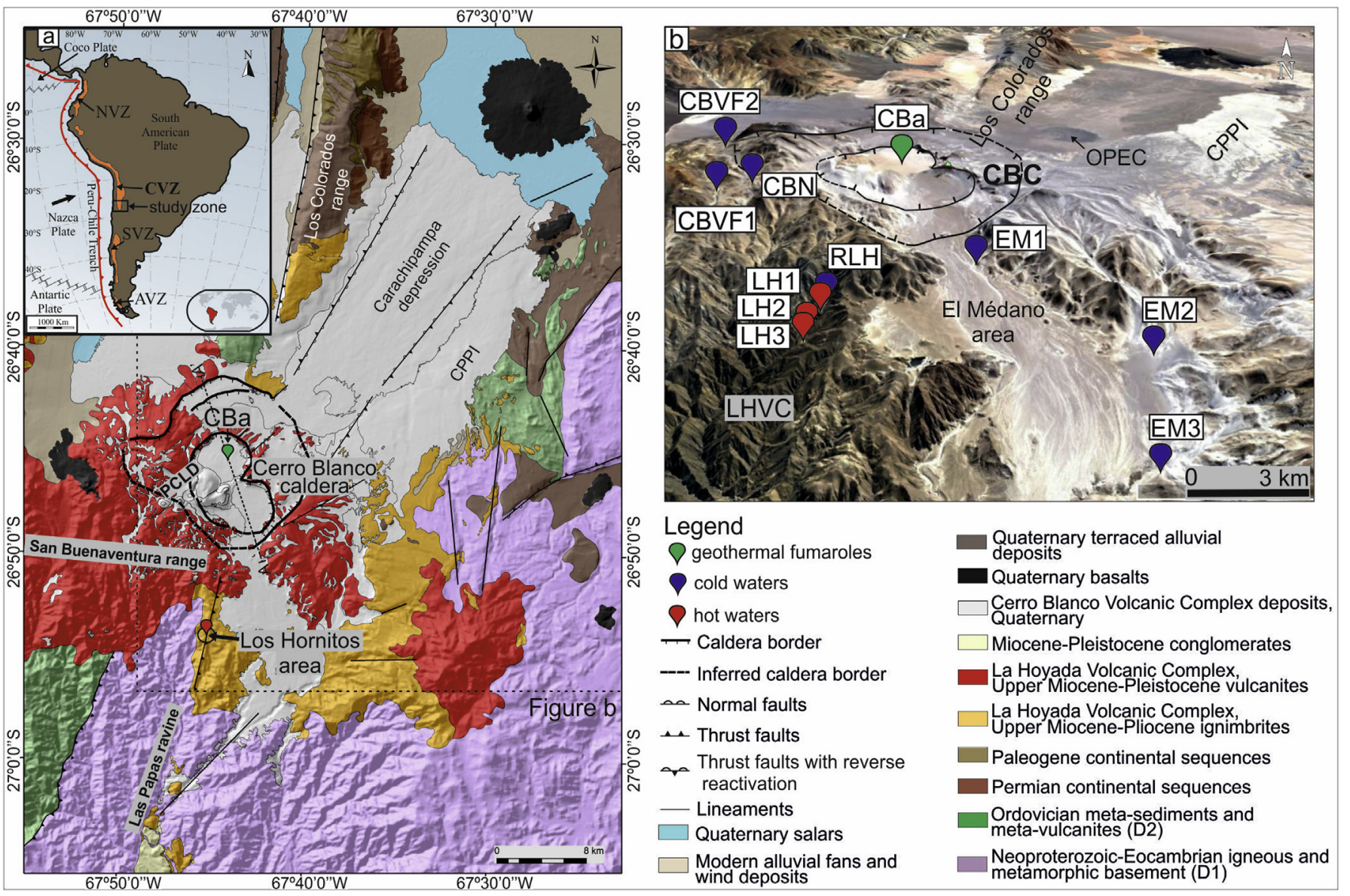

Fig. 1. (a) Geological map (Báez et al., 2015) and (b) satellite image (Google Earth data) of the study area with the location of the sampling sites. CBa: geothermal fumarole. EM1, EM2 and EM3: El Médano cold springs. CBVF1 and CBVF2: La Hoyada cold springs. CBN: snow sample. RLH: creek water. LH1, LH2 and LH3: Los Hornitos hot springs. CBC: Cerro Blanco Caldera. PCLD: post-caldera lava domes. CPPI: Campo de la Piedra Pómez ignimbrite. OPEC: El Oculto phreatic explosive crater. NVZ: Northern volcanic zone. CVZ: Central volcanic zone. SVZ: Southern volcanic zone. AVZ: Austral volcanic zone.

Cerro Pabellón 48 MW installed power geothermal plant, in Chile. Prior to this, a $0.67 \mathrm{MW}$ binary prototype unit was in operation for a short period of time until 1996 (Bertani, 2010) in the Copahue geothermal field (Neuquén Province, Argentina). During the last years, there has been a renewed interest for developing the geothermal resource in Argentina due to the increasing demand for new sources of energy. The aforementioned fostered by a recently regulatory framework aimed to promote the use of non-conventional renewable energies. The most interesting high-temperature geothermal systems in Argentina are located in the western sector (Central and Southern Volcanic Zones of the Andes), likely associated with the Neogene-Quaternary volcanic arc (Fig. 1a). Geothermal systems related to magmatic intrusions are generally the hottest $\left(\mathrm{T} \geq 220^{\circ} \mathrm{C}\right)$ and most prolific producers of geothermal electricity worldwide (Stimac et al., 2015). Particularly, young silicic calderas, as Cerro Blanco (Northwestern Argentina), are ideal geological settings for the development of large long-lived geothermal systems (e.g. Campi Flegrei, Long Valley Caldera; Goff and Janik, 2000). The formation of a caldera requires the accumulation of magma at shallow depth, which implies a high heat flux in the upper crust. Moreover, faulted and fractured intra-caldera rocks can act as great reservoirs for fluids, due to their secondary permeability capable to trap meteoric waters, which are heated by subjacent magmas (Stimac et al., 2015). In addition, the Cerro Blanco Caldera (CBC; Fig. 1a and b) represents an important geothermal target because it is the youngest collapse caldera system in the Southern Central Andes (Middle Pleistocene-Holocene; Viramonte et al., 2008; Montero-López et al., 2009, 2010; Fernández-Turiel et al., 2019, Báez et al., 2015). CBC is part of the volcanic activity related to the Cerro Blanco Volcanic Complex
(CBVC), located in the southern limit of the Andean Plateau (Catamarca Province, Argentina). Despite the existence of recent publications focused on the volcanological aspects of the CBVC (Fernández-Turiel et al., 2019; Báez et al., 2015, 2017), the hydrothermal activity in this area is still scarcely investigated (Viramonte et al., 2005a; Chiodi, 2015). Fluid geochemistry constitutes a valuable tool for geothermal prospections and the development pre-feasibility investigations (e.g. D'Amore and Panichi, 1980; Giggenbach, 1991, 1997a). In this work, we present the results of a geochemical survey carried out on the hydrothermal manifestations related to $\mathrm{CBC}$ to provide insights into (i) the physicochemical conditions acting on the fluid reservoir, (ii) the primary fluid source(s) and (iii) secondary processes controlling the fluid chemistry. Eventually, the very first hydrogeochemical conceptual model and a preliminary estimation of the geothermal potential are proposed.

\section{Geological and volcanological features}

CBVC (Fig. 1a and b) was recognized as a nested caldera system with associated domes and pyroclastic deposits (Seggiaro et al., 2000; Arnosio et al., 2005; Viramonte et al., 2005a, 2005b). All erupted products are rhyolitic/rhyodacitic in composition and middle Pleistocene-Holocene in age (Báez et al., 2015 and references therein). CBVC was built on a complex basement that includes (i) NeoproterozoicLower Paleozoic metamorphic rocks of low to medium grade, Ordovician volcano-sedimentary sequences, (ii) Upper Paleozoic continental deposits and (iii) Cenozoic deposits that infill Paleogene foreland basins (Seggiaro et al., 2000). Furthermore, CBVC overlies a Miocene- 
Pleistocene volcanic sequence consisting of several andesitic-dacitic stratovolcanoes aligned in a SW-NE direction (La Hoyada Volcanic Complex, LHVC), which constitutes the San Buenaventura range (Seggiaro et al., 2000; Montero López et al., 2010; Bustos et al., 2019). CBVC stratigraphy consists of two main ignimbrite units separated by major unconformities that represent periods of quiescent volcanic activity (Báez et al., 2015). The oldest is Campo de la Piedra Pómez Ignimbrite (Pleistocene) related to the largest caldera collapse in the evolution of the CBVC. The youngest ignimbrite unit is Cerro Blanco Ignimbrite (Holocene) that represents further reactivations of the CBVC resulting in the nesting of at least two collapse calderas. The youngest activity in the CBVC also includes the emplacement and destruction of several lava domes (Báez et al., 2017). It is important to highlight that CBVC had at least two large-scale eruptions (Volcanic Explosivity Index $\geq 6$ ) over the past 100,000 years including one of the greatest Holocene volcanic events in the Central Andes (Fernández-Turiel et al., 2019; Báez et al., 2015). In addition, the CBC is subsiding at an average velocity of $0.87 \mathrm{~cm} /$ year (Brunori et al., 2013; Henderson and Pritchard, 2013; López, 2016) and hosts an active geothermal system (Viramonte et al., 2005a; Chiodi, 2015; Chiodi et al., 2017). The main tectonic structures in the study area consist of reverse faults with NNESSW to NE-SW orientation in response to the NW-SE shortening associated with vertical extension, developed in the Southern Puna from Miocene to Pliocene (Marrett and Emmerman, 1992). From Pliocene to present, the tensional field changed to a NE-SW extensional regime associated with strike-slip and late normal reactivation of reverse faults (Marrett and Emerman, 1992; Montero López et al., 2010). The recent extension in the Souther Puna was associated either with the gravitational collapse of the plateau or episodes of lithospheric foundering and delamination under Puna's thick crust (Ducea et al., 2013; Schoenbohm and Strecker, 2009).

\section{Geothermal manifestations at CVCB}

According to the classification proposed by Moeck (2014), the studied geothermal system can be interpreted as a volcanic field type due to, as follows: i) its location in a magmatic arc above a subduction zone in a convergent plate margin in association with recent magmatism (recent magmatism sensu McCoy-West et al., 2011), ii) the occurrence of a magma chamber providing the heat source, iii) the structural control on fluid circulation. The surface manifestations of the Cerro Blanco Geothermal System (CBGS) are situated in the northern sector of CBC $\left(26.7588^{\circ}\right.$ S- $67.7394^{\circ} \mathrm{W}, 4132 \mathrm{~m}$ a.s.l.) associated with a NE-SW fault system that also controlled the emplacement of post-caldera lava domes (Figs. 1a and 2a,b,; Arnosio et al., 2005; Viramonte et al., 2005b; Montero López et al., 2010; Báez et al., 2017). In this area, deposits of dilute pyroclastic density currents and breccias produced by phreatic explosions associated with the hydrothermal activity were recognized (Fig. 2a,d; Viramonte et al., 2005a). Viramonte et al. (2005a) described as about $40 \mathrm{~cm}$ thick silicic plateau constituted by amorphous silica, opal and quartz, suggesting the occurrence of a relatively intense hydrothermal activity in the past. In the proximity of the fumarole vents, alteration zones mainly formed by boehmite, kaolinite and alunite were recognized (Viramonte et al., 2005a). The fumaroles have temperatures up to $93.7^{\circ} \mathrm{C}$ and in the surrounding areas the average ground temperature is $92^{\circ} \mathrm{C}$ (Fig. $2 \mathrm{~b}$ and c). In addition, close to the caldera (Fig. 1b), there are two sectors where mineral and thermal manifestations were recognized and likely associated with CBGS (Chiodi et al., 2017): El Médano (EM1) and Los Hornitos (LH1-LH3). In El Médano area, low-temperature (up to $\left.17^{\circ} \mathrm{C}\right) \mathrm{Na}^{+}-\mathrm{HCO}_{3}{ }^{-}\left(\mathrm{SO}_{4}{ }^{-2}\right)$ springs emerge at the contact between the Miocene volcanic rocks of LHVC and CBI. In Los Hornitos area, several hot springs and bubbling pools having a $\mathrm{Na}^{+}$. $\mathrm{Cl}^{-}\left(\mathrm{HCO}_{3}{ }^{-}\right)$composition were observed in three sectors along a NNESSW-oriented ravine cutting volcanic rocks of LHVC. Each of these sectors show clusters of hydrothermal discharges, with relatively large variability in terms of flow rate and temperature (between 32 and $67.4^{\circ} \mathrm{C}$ ), emerging from travertine domes and some of them directly into a creek. A peculiar feature of this area is the presence of extinct geysers, which have throats or vents that emerge from cone-shaped mounds, up to $2 \mathrm{~m}$ high (Fig. 2e and f). Petrographic and x-ray diffraction studies in the tuffs and travertines reported that Calcite is the predominant mineral, with the exception of the geyser vent-surroundings where various types of salts, Silica and Aragonite occur (Mors et al., 2016).

\section{Sampling and analytical methods}

\subsection{Water and gas sampling}

Nine water samples from 3 bubbling pools (LH1-LH3), 4 cold springs (EM1, EM3, CBVF1-CBVF2), 2 creeks (EM2 and RLH) and 1 snow sample (CBN) were collected. Water temperature, $\mathrm{pH}$ and electrical conductivity were measured in the field using portable instruments (Hanna HI 98195; accuracy: $\pm 0.15^{\circ} \mathrm{C}, \pm 0.02$ and $\pm 1 \%$, respectively). Alkalinity (expressed as $\mathrm{HCO}_{3}{ }^{-}$) and silica were analyzed in situ by (i) acidimetric titration using $\mathrm{HCl} 0.03 \mathrm{~N}$, phenolphthalein and bromophenol blue as indicators, and (ii) molecular spectrophotometry (Hanna HI 96770C; $\pm 1 \mathrm{mg} / \mathrm{l}$ ), respectively (Table 1). At each sample point, 4 aliquots ( 2 filtered samples at $0.45 \mu \mathrm{m}$ and acidified with ultrapure $\mathrm{HCl}$ and $\mathrm{HNO}_{3}$ for the analysis of major cations and trace elements, respectively, 1 filtered sample for the analysis of anions and 1 unfiltered sample for the analysis of water isotopes) were collected.

Gas samples from bubbling pools (LH1, LH2, LH3) were sampled using a plastic funnel up-side-down positioned above the bubbles and connected through tygon tubes to the sampling flasks. The latter consisted of (i) a pre-evacuated $60 \mathrm{~mL}$ glass thorion tapped bottle filled with $20 \mathrm{~mL}$ of a $4 \mathrm{~N} \mathrm{NaOH}$ solution for the analysis of the gas chemical composition (Giggenbach and Goguel, 1989) and (ii) a pre-evacuated $60 \mathrm{~mL}$ glass flask for the analysis of the carbon isotopic ratio in $\mathrm{CO}_{2}$ (Vaselli et al., 2006). One fumarole (CBa) was sampled with the same devices used for the bubbling gases. At this sampling site, a steam condensate (for the analysis of the $\delta \mathrm{D}$ and $\delta^{18} \mathrm{O}$ values of water) was collected using a water-cooler glass condensing system.

One water sample (EM1) for the analysis of the dissolved gases was collected in a $50 \mathrm{~mL}$ glass flask equipped with a rubber septum. In the laboratory, a $10 \mathrm{cc}$ headspace was created in the flasks by injecting $\mathrm{H}_{2}$ through the septum. Following a modified method based on Chiodini (1996), the chemical composition was computed by considering the measured concentrations of gases stored in the headspace on the basis of: i) headspace gas pressure and volume, ii) volume of water in the flask and iii) solubility coefficients of each gas compound (Whitfield, 1978). The location (coordinates) of the sampling sites is reported in Tables 1 and 2 and plotted in Fig. 1 b.

\subsection{Chemical and isotopic analyses of water samples}

Major cations $\left(\mathrm{Na}^{+}, \mathrm{K}^{+}, \mathrm{Ca}^{2+}, \mathrm{Mg}^{2+}, \mathrm{Li}^{+}\right.$and $\left.\mathrm{NH}_{4}^{+}\right)$and anions $\left(\mathrm{F}^{-}, \mathrm{Cl}^{-} \mathrm{SO}_{4}{ }^{2}{ }^{-}, \mathrm{Br}^{-}\right.$and $\left.\mathrm{NO}_{3}{ }^{-}\right)$were analyzed by ion-chromatography (IC: Metrohm 861 and 761, respectively). The analytical error was $\leq 5 \%$. Boron was analyzed by molecular spectrophotometry (MS; Beckman DU 520) using the Azomethine-H method (Bencini, 1985). The analytical error was $\leq 5 \%$.

Trace elements were analyzed by Inductively Coupled Plasma Optical Emission Spectrometry (ICP-OES) using an Optima 8000 PerkinElmer spectrometer. The analytical error was $\leq 10 \%$.

The ${ }^{18} \mathrm{O} /{ }^{16} \mathrm{O}$ and ${ }^{2} \mathrm{H} /{ }^{1} \mathrm{H}$ ratios in water (expressed as $\delta^{18} \mathrm{O}-\mathrm{H}_{2} \mathrm{O}$ and $\delta^{2} \mathrm{H}-\mathrm{H}_{2} \mathrm{O} \%$ vs. V-SMOW, respectively) were analyzed using an Ultra High-Precision Isotopic Water Analizer Picarro L2130-i laser spectrometer. The analytical errors for $\delta^{18} \mathrm{O}-\mathrm{H}_{2} \mathrm{O}$ and $\delta^{2} \mathrm{H}-\mathrm{H}_{2} \mathrm{O}$ values were $\pm 0.25 \%$ and $\pm 1.20 \%$, respectively. 


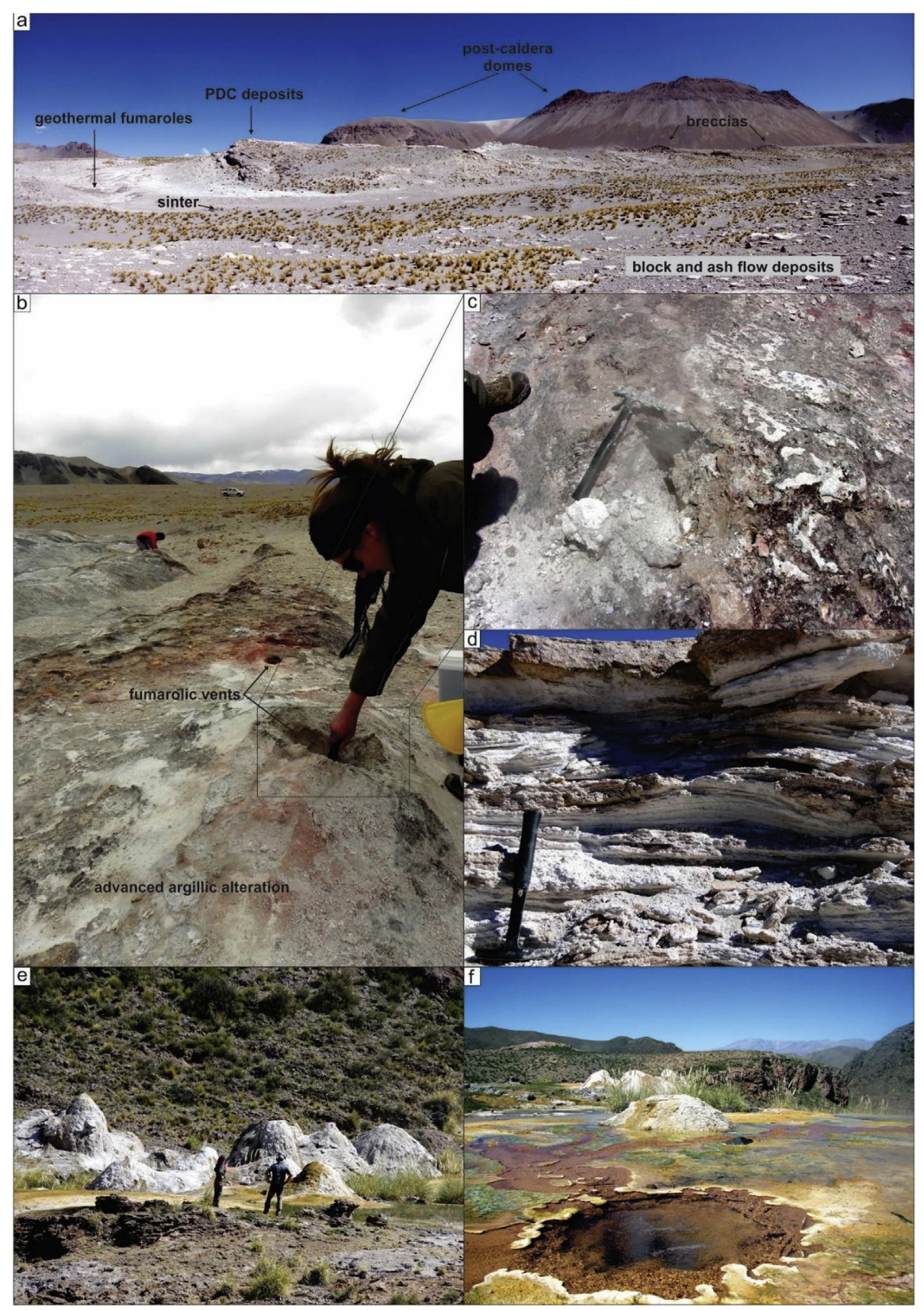

Fig. 2. (a) Panoramic view (toward SW) of the deposits associated to CBGS. (b) General view of the geothermal fumaroles and the alteration zone; (c) detailed view of the geothermal fumarole selected for sampling (CBa); (d) dilute pyroclastic density current deposits (PDC deposits); (e) general view of the cone-shaped morphology of the extinct geysers in Los Hornitos thermal area; (f) detailed view of the sampled bubbling pool (LH2) in Los Hornitos thermal area.

\subsection{Chemical and isotopic analysis of dissolved and bubbling gases}

Inorganic gases $\left(\mathrm{N}_{2}, \mathrm{O}_{2}, \mathrm{H}_{2}, \mathrm{CO}, \mathrm{Ar}, \mathrm{Ne}\right.$ and $\left.\mathrm{He}\right)$ in the headspace of the soda flasks, as well as those collected in the headspace of the dissolved gas vial $\left(\mathrm{N}_{2}, \mathrm{O}_{2}, \mathrm{CO}, \mathrm{Ar}, \mathrm{He}, \mathrm{Ne}, \mathrm{CO}_{2}\right.$ and $\left.\mathrm{H}_{2} \mathrm{~S}\right)$, were analyzed by gas chromatography (GC) using a Shimadzu 15A instrument equipped with a Thermal Conductivity Detector (TCD). Carbon dioxide and $\mathrm{H}_{2} \mathrm{~S}$ in the alkaline solution were analyzed as $\mathrm{CO}_{3}{ }^{2-}$, by acidimetric titration with a $\mathrm{HCl} 0.1 \mathrm{~N}$ solution, and $\mathrm{SO}_{4}{ }^{2-}$, by IC after oxidation with $\mathrm{H}_{2} \mathrm{O}_{2}$, respectively. Light hydrocarbons, including $\mathrm{CH}_{4}$, were determined by using a Shimadzu 14A gas chromatograph (GC), equipped with a 10-m-long stainless-steel column packed with Chromosorb PAW $80 / 100$ mesh coated with $23 \%$ SP 1700 and a Flame Ionization Detector (FID). The analytical errors for GC analyses were $\leq 5 \%$.
The ${ }^{13} \mathrm{C} /{ }^{12} \mathrm{C}$ ratio of dissolved $\mathrm{CO}_{2}$ (expressed as $\delta^{13} \mathrm{C}-\mathrm{CO}_{2} \%$ vs. $\mathrm{V}$ $\mathrm{PDB}$ ) in EM1 was computed from the $\delta^{13} \mathrm{C}$ values measured in $\mathrm{CO}_{2}$ of the flask headspace $\left(\delta^{13} \mathrm{C}-\mathrm{CO}_{2 \mathrm{STRIP}}\right)$, using the $\varepsilon_{1}$ factor for gas-water isotope equilibrium proposed by Zhang et al. (1995), as follows:

$\varepsilon_{1}=\delta^{13} \mathrm{C}-\mathrm{CO}_{2} \delta^{13} \mathrm{C}-\mathrm{CO}_{2 \mathrm{STRIP}}=0.0049 \times \mathrm{T}\left({ }^{\circ} \mathrm{C}\right) 1.31$

The $\delta^{13} \mathrm{C}-\mathrm{CO}_{2 \mathrm{STRIP}}$ analysis was carried out with a Finningan Delta Plus mass spectrometer after extracting and purifying $\mathrm{CO}_{2}$ by using liquid $\mathrm{N}_{2}$ and $\mathrm{N}_{2}$-trichloroethylene cryogenic traps (Evans et al., 1998; Vaselli et al., 2006). The ${ }^{13} \mathrm{C} /{ }^{12} \mathrm{C}$ ratios of $\mathrm{CO}_{2}$ (expressed as $\delta^{13} \mathrm{C}-\mathrm{CO}_{2} \%$ vs. V-PDB) of the bubbling gas flasks were measured by using $2 \mathrm{~mL}$ of the soda solution after the addition of $\sim 5 \mathrm{~mL}$ of anhydrous phosphoric acid for the extraction of $\mathrm{CO}_{2}$. Isotopic equilibration was achieved in a thermal bath at the temperature of $25 \pm 0.1^{\circ} \mathrm{C}$ for at 


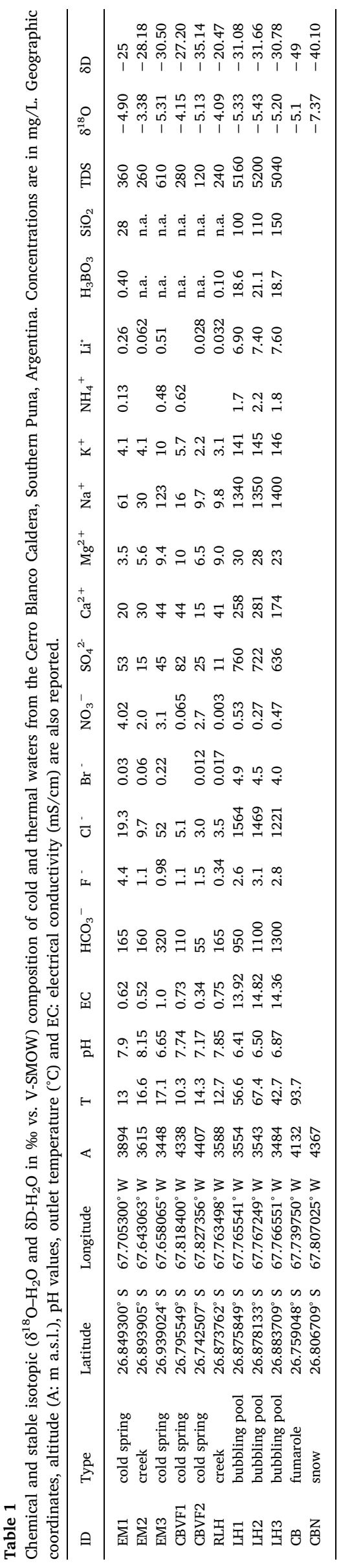

Table 2

Chemical composition (in $\mu \mathrm{g} / \mathrm{L}$ ) of minor elements of thermal waters from Los Hornitos area, Southern Puna, Argentina.

\begin{tabular}{lllllllll}
\hline ID & Mn & Fe & As & Se & Rb & Sr & Cs & Ba \\
\hline LH1 & 370 & 440 & 1600 & 19 & 1310 & 5000 & 1300 & 71 \\
LH2 & 350 & 280 & 1630 & 17 & 1330 & 5060 & 1390 & 67 \\
LH3 & 200 & 98 & 1680 & 9 & 1550 & 3920 & 2160 & 61 \\
\hline
\end{tabular}

least $8 \mathrm{~h}$. The extracted $\mathrm{CO}_{2}$ was treated as previously described for the $\mathrm{CO}_{\text {2STRIP. The }}{ }^{13} \mathrm{C} /{ }^{12} \mathrm{C}$ ratios were analyzed with a Finningan Delta Plus mass spectrometer. Carrara and San Vincenzo marbles (Internal), as well as NBS18 and NBS19 (International) standards were used to estimate the external precision. The analytical errors were $\pm 0.05 \% 0$ and $\pm 0.1 \%$, respectively. The Helium isotopic ratios (expressed as R/ $\mathrm{Ra}$, where $\mathrm{R}$ is the ${ }^{3} \mathrm{He} /{ }^{4} \mathrm{He}$ measured ratio and $\mathrm{Ra}$ is the ${ }^{3} \mathrm{He} /{ }^{4} \mathrm{He}$ ratio in the air: $1.39 \times 10^{-6}$; Mamyrin and Tolstikhin, 1984) and those of ${ }^{4} \mathrm{He} /{ }^{20} \mathrm{Ne}$ were determined by using a double collector mass spectrometer (VG 5400-TFT) according to the method described by Inguaggiato and Rizzo (2004). The analytical error was $\pm 1 \%$. The R/ Ra values were corrected for atmospheric contamination using the ${ }^{4} \mathrm{He} /{ }^{20} \mathrm{Ne}$ ratios (Poreda and Craig, 1989a,b), as follows:

$\mathrm{Rc} / \mathrm{Ra}=\left[\left(\mathrm{R} / \mathrm{Ra}_{\text {measured }}\right)-\mathrm{r}\right] /(1-\mathrm{r})$

where $\mathrm{r}$ is $\left({ }^{4} \mathrm{He} /{ }^{20} \mathrm{Ne}\right)_{\text {air }} /\left({ }^{4} \mathrm{He} /{ }^{20} \mathrm{Ne}\right)_{\text {measured }}$ and that of $\left({ }^{4} \mathrm{He} /{ }^{20} \mathrm{Ne}\right)_{\text {air }}$ is 0.421 at the estimated altitude of recharge of approximately $4000 \mathrm{~m}$ (Hoke et al., 1994).

\section{Results}

\subsection{Chemical and stable isotopic $\left(\delta^{18} O\right.$ and $\left.\delta D\right)$ composition of waters}

The chemical-physical parameters as well as the chemical and isotopic composition of the CBC waters are listed in Table 1. Based on the chemical composition, 3 groups of waters can be distinguished (Fig. 3):

1) Group $1\left(\mathrm{Na}^{+}-\mathrm{Cl}^{-}\left(\mathrm{HCO}_{3}^{-}\right)\right.$waters) includes thermal waters ( $\mathrm{LH} 1$, LH2 and LH3 samples) emerging from the Los Hornitos zone, which shows nearly neutral to slightly acidic $\mathrm{pH}$ values (from 6.87 to 6.41), relatively high outlet temperatures (up to $67.4^{\circ} \mathrm{C}$ ) and TDS values (up to $5200 \mathrm{mg} / \mathrm{L}$ ). These waters are also characterized by relatively high concentrations of $\mathrm{HCO}_{3}{ }^{-}$(from 950 to $1300 \mathrm{mg} / \mathrm{L}$ ), $\mathrm{SO}_{4}{ }^{2-}$ (up to $760 \mathrm{mg} / \mathrm{L}$ ), $\mathrm{SiO}_{2}$ (up to $150 \mathrm{mg} / \mathrm{L}$ ), B (up to $21 \mathrm{mg} / \mathrm{L}$ ), $\mathrm{Li}^{+}$(up to $7.6 \mathrm{mg} / \mathrm{L}$ ), $\mathrm{Br}^{-}$(up to $4.9 \mathrm{mg} / \mathrm{L}$ ), $\mathrm{F}^{-}\left(2.8 \mathrm{mg} / \mathrm{L}\right.$ ) and $\mathrm{NH}_{4}{ }^{+}$ (up to $2.8 \mathrm{mg} / \mathrm{L}$ ). The concentrations of $\mathrm{Na}^{+}$(up to $1400 \mathrm{mg} / \mathrm{L}$ ) are one order of magnitude higher than those of the other cations.

2) Group $2\left(\mathrm{Na}^{+}\left(\mathrm{K}^{+}\right)-\mathrm{HCO}_{3}{ }^{-}\right.$waters$)$, including the EM1 and EM3 cold springs and the EM2 creek from El Médano area, shows relatively low outlet temperatures $\left(\leq 17.1^{\circ} \mathrm{C}\right), \mathrm{pH}$ values ranging between 6.65 and 8.15, and low TDS values (up to $610 \mathrm{mg} / \mathrm{L}$ ).

3) Group $3\left(\mathrm{Ca}^{2+}-\mathrm{HCO}_{3}{ }^{-}\right.$waters) refers to two cold springs (CBVF1 and CBVF2) located within the western sector of the CBC, where strongly altered rocks of the LHVC crop out, and the RLH creek from Los Hornitos zone. These samples have slightly alkaline $\mathrm{pH}$ (between 7.17 and 7.85) and show low outlet temperatures $\leq 14.3^{\circ} \mathrm{C}$ and TDS values (up to $280 \mathrm{mg} / \mathrm{L}$ ).

Trace element concentrations of the thermal water samples are listed in Table 2. The highest values were measured for $\mathrm{Sr}, \mathrm{Cs}$, As and $\mathrm{Rb}$ (up to 5,060, 2,160, 1680 and $1550 \mu \mathrm{g} / \mathrm{L}$, respectively), followed by $\mathrm{Fe}, \mathrm{Mn}, \mathrm{Ba}$ and Se (up to 440, 370, 71 and $19 \mu \mathrm{g} / \mathrm{L}$, respectively).

The oxygen and hydrogen isotopic data (expressed as $\delta^{18} \mathrm{O}-\mathrm{H}_{2} \mathrm{O}$ and $\delta \mathrm{D}-\mathrm{H}_{2} \mathrm{O} \%$ vs. V-SMOW, respectively) for the thermal waters vary in a narrow range, from -5.43 to -5.20 and from -31.66 to $-30.78 \%$ vs. V-SMOW, respectively, whereas those of the cold springs and creeks 


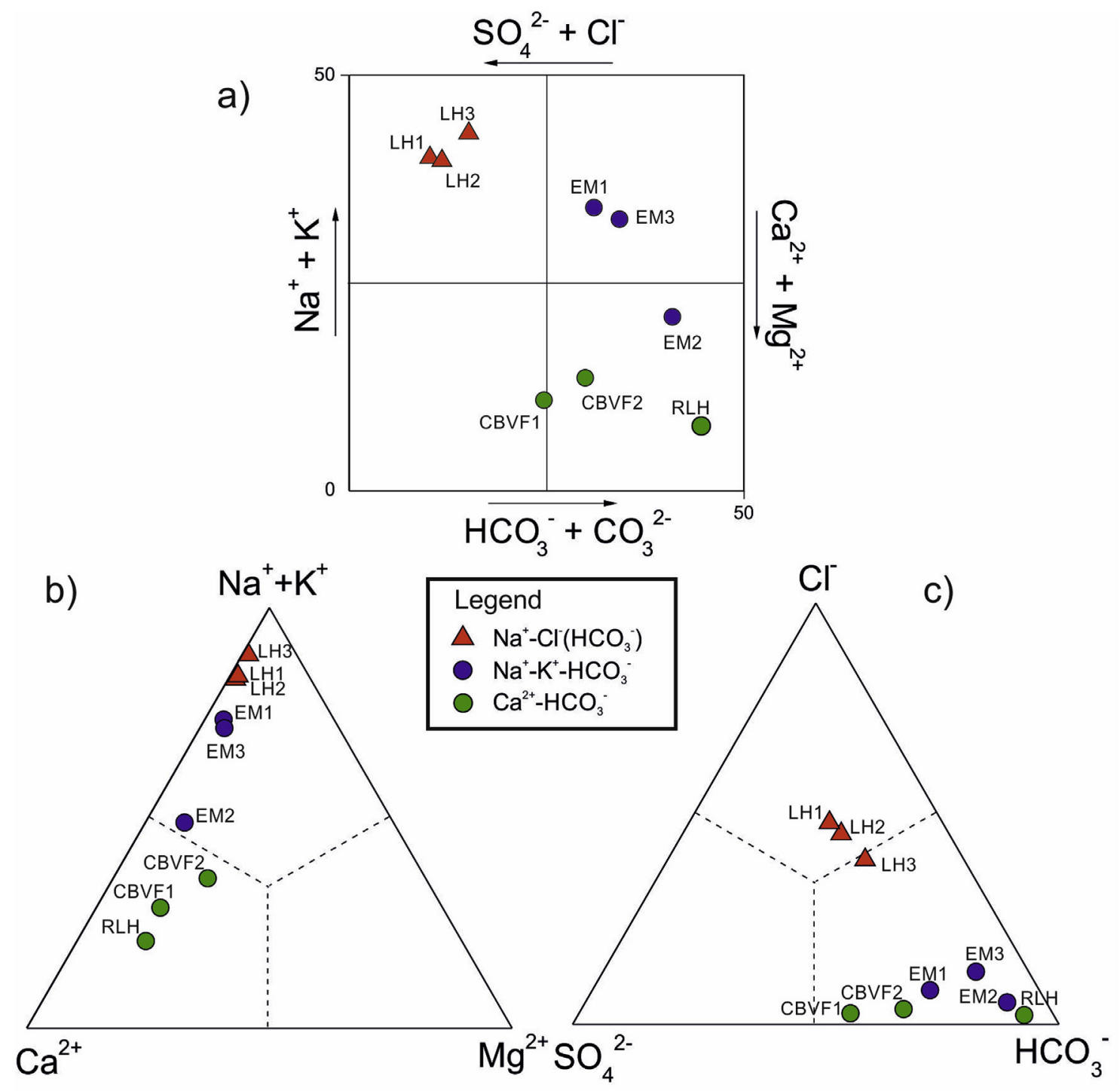

Fig. 3. (a) Langelier-Ludwing square diagram (Langelier and Ludwig, 1942), (b) $\mathrm{Ca}^{2+}-\left(\mathrm{Na}^{+}+\mathrm{K}^{+}\right)-\mathrm{Mg}^{2+}$ and (c) $\mathrm{SO}_{4}{ }^{2-}-\mathrm{Cl}^{-}-\mathrm{HCO}_{3}{ }^{-}$ternary diagrams for cold and thermal waters from the CBC (in mg/L). Symbols are: red triangle: thermal waters from Los Hornitos area; blue circle: cold waters from El Médano area; green circle: cold waters collected from the western sector of the caldera and from the creek from Los Hornitos area. (For the interpretation of the references to color in this figure legend, the reader is referred to the web version of this article.)

vary from -5.31 to -3.38 and from -35.14 to $-20.47 \%$ vs. VSMOW, respectively. The $\delta^{18} \mathrm{O}-\mathrm{H}_{2} \mathrm{O}$ and $\delta \mathrm{D}-\mathrm{H}_{2} \mathrm{O}$ values of the snow sample (CBN) are significantly more negative than those determined in the water samples, being -7.37 and $-40.1 \%$ vs. V-SMOW, respectively. Finally, the $\delta^{18} \mathrm{O}-\mathrm{H}_{2} \mathrm{O}$ and $\delta \mathrm{D}-\mathrm{H}_{2} \mathrm{O}$ values of the steam condensate (CB) from the fumarole are -5.1 and $-49 \%$ vs. V-SMOW, respectively (Table 1 ).

\subsection{Chemical and stable isotopic $\left({ }^{13} \mathrm{C}-\mathrm{CO}_{2}\right.$ and $\mathrm{R} / \mathrm{Ra}$ ) composition of gases}

The outlet temperature of the $\mathrm{CBa}$ fumarole is $93.7^{\circ} \mathrm{C}$ (Table 3). The chemical composition of this gas sample (Table 3) is dominated by water vapor ( $89 \%$ by vol.), whereas $\mathrm{CO}_{2}$ is largely the most abundant dry gas compound $(950 \mathrm{mmol} / \mathrm{mol})$, followed by $\mathrm{N}_{2}(36 \mathrm{mmol} / \mathrm{mol})$, $\mathrm{H}_{2} \mathrm{~S}(14 \mathrm{mmol} / \mathrm{mol})$ and $\mathrm{H}_{2}(0.037 \mathrm{mmol} / \mathrm{mol})$. Helium is present at relatively low concentrations $(0.0014 \mathrm{mmol} / \mathrm{mol})$ whereas $\mathrm{CO}$ was below the analytical detection limit $(0.001 \mathrm{mmol} / \mathrm{mol})$. The concentrations of the atmospheric gases $\left(\mathrm{O}_{2}, \mathrm{Ar}\right.$ and $\left.\mathrm{Ne}\right)$ are $0.71,0.34$ and $0.00018 \mathrm{mmol} / \mathrm{mol}$, respectively. Methane is the most abundant organic gas $(0.022 \mathrm{mmol} / \mathrm{mol})$, whereas heavier hydrocarbons have significantly lower concentrations ranging from $0.00011 \mathrm{mmol} / \mathrm{mol}$ (i$\left.\mathrm{C}_{5} \mathrm{H}_{12}\right)$ to $0.0054 \mathrm{mmol} / \mathrm{mol}\left(\mathrm{C}_{2} \mathrm{H}_{6}\right)$. The chemical composition of the bubbling pools (Table 3 ), expressed as dry gas fraction since water vapor mostly condensed in the liquid phase at the surface, is dominated by $\mathrm{CO}_{2}$ (between 730 and $880 \mathrm{mmol} / \mathrm{mol}$ ) and $\mathrm{N}_{2}$ (up to $260 \mathrm{mmol} /$ mol), with minor concentrations of $\mathrm{CH}_{4}$ (up to $0.011 \mathrm{mmol} / \mathrm{mol}$ ), $\mathrm{Ar}$ (up to $5.9 \mathrm{mmol} / \mathrm{mol}$ ), $\mathrm{O}_{2}$ (up to $2.5 \mathrm{mmol} / \mathrm{mol}$ ), He (up to $0.0019 \mathrm{mmol} / \mathrm{mol}$ ) and $\mathrm{Ne}$ (up to $0.0031 \mathrm{mmol} / \mathrm{mol}$ ). Hydrogen was detected only in LH2 sample $(0.011 \mathrm{mmol} / \mathrm{mol})$, with concentrations comparable with that measured in the fumarole, whilst $\mathrm{H}_{2} \mathrm{~S}$, CO and hydrocarbons were not detected. The chemical composition of the EM1 dissolved gases (Table 3 ) is characterized by dominant $\mathrm{CO}_{2}$ and $\mathrm{N}_{2}$ (up to 560 and $420 \mathrm{mmol} / \mathrm{mol}$, respectively), and relatively high concentrations of atmospheric gases (Ar, $\mathrm{O}_{2}$ and Ne: 9.6, 7.9 and $0.0062 \mathrm{mmol} / \mathrm{mol}$, respectively), whereas those of $\mathrm{He}$ and $\mathrm{CH}_{4}$ were 0.054 and $0.011 \mathrm{mmol} / \mathrm{mol}$, respectively. Hydrogen, $\mathrm{H}_{2} \mathrm{~S}$, $\mathrm{CO}$ and hydrocarbons were not detected.

The isotopic composition of the gas samples is listed in Table 3. The $\delta^{13} \mathrm{C}-\mathrm{CO}_{2}$ values span in a narrow range, from $-9.56 \%$ to $-5.23 \%$ vs. 


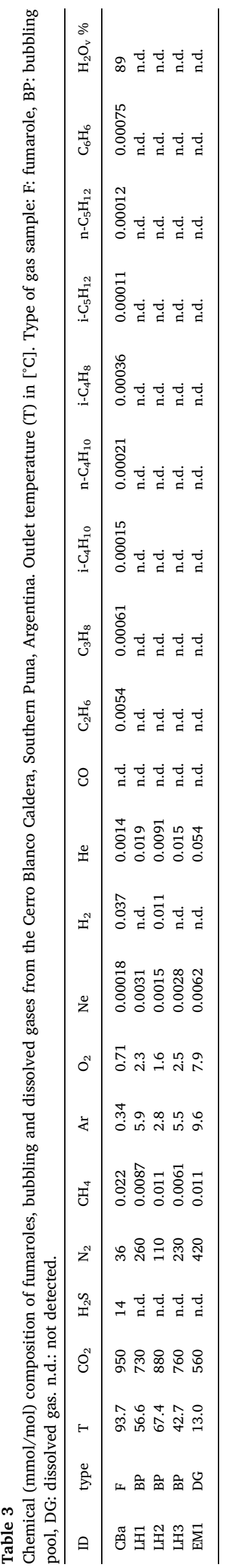

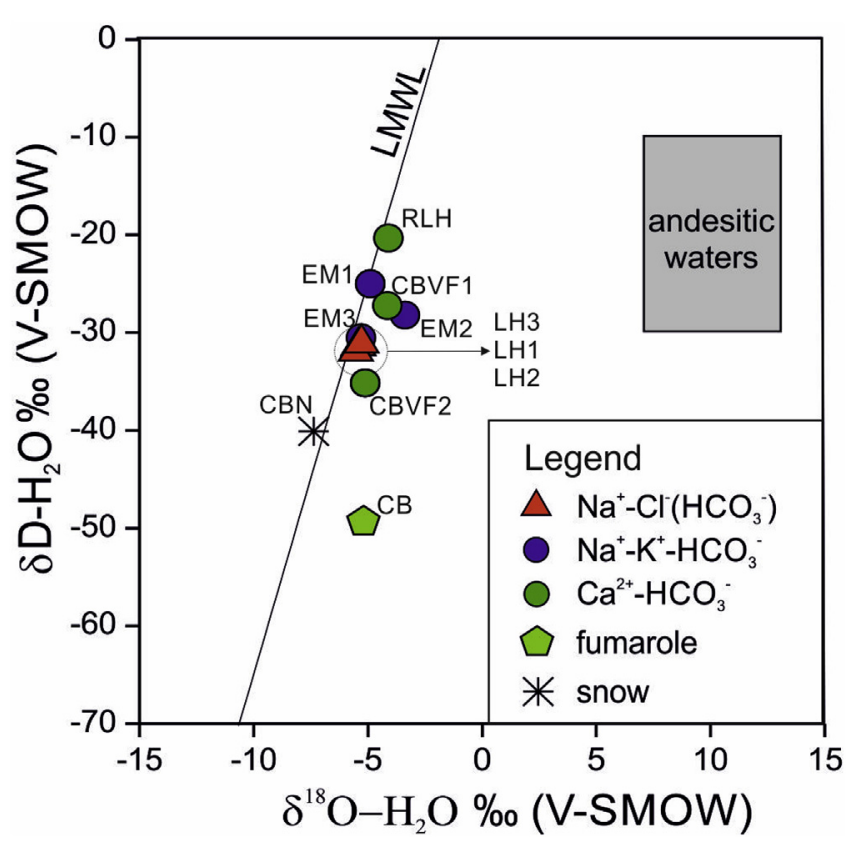

Fig. 4. $\delta \mathrm{D}-\mathrm{H}_{2} \mathrm{O}$ vs. $\delta^{18} \mathrm{O}-\mathrm{H}_{2} \mathrm{O}$ binary diagram for cold and thermal waters from the CBC. The Local Meteoric Water Line (LMWL: $(\delta \mathrm{D}=(8.01 \pm 0.08)$ $\delta^{18} \mathrm{O}+(15.2 \pm 0.7) \%$; Gonfiantini et al., 2001) is also shown. Symbols as in Fig. 3.

V-PDB. The Rc/Ra (where Rc is the corrected isotopic ratio calculated according to the ${ }^{4} \mathrm{He} /{ }^{20} \mathrm{Ne}$ ratio) values measured in two selected samples (CBa and LH2) were 2.16 and 1.11, respectively.

\section{Discussion}

\subsection{Processes controlling the chemical and isotopic composition of waters}

According to the $\delta^{18} \mathrm{O}-\mathrm{H}_{2} \mathrm{O}$ and $\delta \mathrm{D}-\mathrm{H}_{2} \mathrm{O}$ diagram (Fig. 4), where the Local Meteoric Water Line (LMWL: $\delta \mathrm{D}=(8.01 \pm 0.08)$ $\delta^{18} \mathrm{O}+(15.2 \pm 0.7) \%$; Gonfiantini et al., 2001) was reported, the CBC waters have a meteoric origin. EM2, CBVF1 and CBVF2 plots slightly off of the LMWL (Fig. 4), possibly due to evaporation in a highaltitude hyper-arid environment, which causes kinetic fractionation that often increases the $\delta^{18} \mathrm{O}$ values of residual surface waters (Gat, 1996; Stewart, 1975; Fiorella et al., 2015; Bershaw et al., 2016), a process also invoked to explain the isotopic data of stream water across the Andean Plateau (Bershaw et al., 2016). The main compositional features of Group 1, i.e. i) relatively high TDS values (up to $5169 \mathrm{mg} / \mathrm{L}$ ), ii) slightly acidic $\mathrm{pH}$, iii) high $\mathrm{Li}^{+}$concentrations and iv) high $\mathrm{B}$ and $\mathrm{Ba}$ concentrations, are typical of hydrothermal fluids related to geothermal and volcanic systems (Giggenbach, 1988, 1991). Relatively high concentrations of As, $\mathrm{Cs}, \mathrm{Rb}$ and $\mathrm{Mn}$ (Table 2), in the range of contents characterizing waters discharges in hydrothermal environment (e.g. Aiuppa et al., 2006; Kaasalainen and Stefánsson, 2012; Wilson et al., 2012; Göb et al., 2013), were also measured. Such high concentrations of $\mathrm{Li}, \mathrm{Rb}$ and $\mathrm{Cs}$ (up to 7.6, 1.5 and $2.1 \mathrm{mg} / \mathrm{L}$ ) are likely related to the high concentrations of these elements in rocks of rhyolitic and andesitic composition (Nicholson, 1993), which were recognized in the study area. Iron concentrations are low $\left({ }^{<} 0.44 \mathrm{mg} / \mathrm{L}\right)$, in the range of those characterizing chloride-rich fluids (Nicholson, 1993). Nevertheless, the $\mathrm{Na}^{+} / \mathrm{Cl}^{-}$mol-ratios (Fig. 5a) are higher than the stoichiometric ratio expected for typical geothermal brines (e.g. Giggenbach, 1997a).

Such a Na ${ }^{+}$excess may be caused by intense leaching of Na-silicates (e.g. feldspars and their alteration products), which are abundant in the study area. The relatively high $\mathrm{HCO}_{3}{ }^{-}$values of these waters (Table 1) were likely due to $\mathrm{CO}_{2}$ dissolution, a process that seems to be 

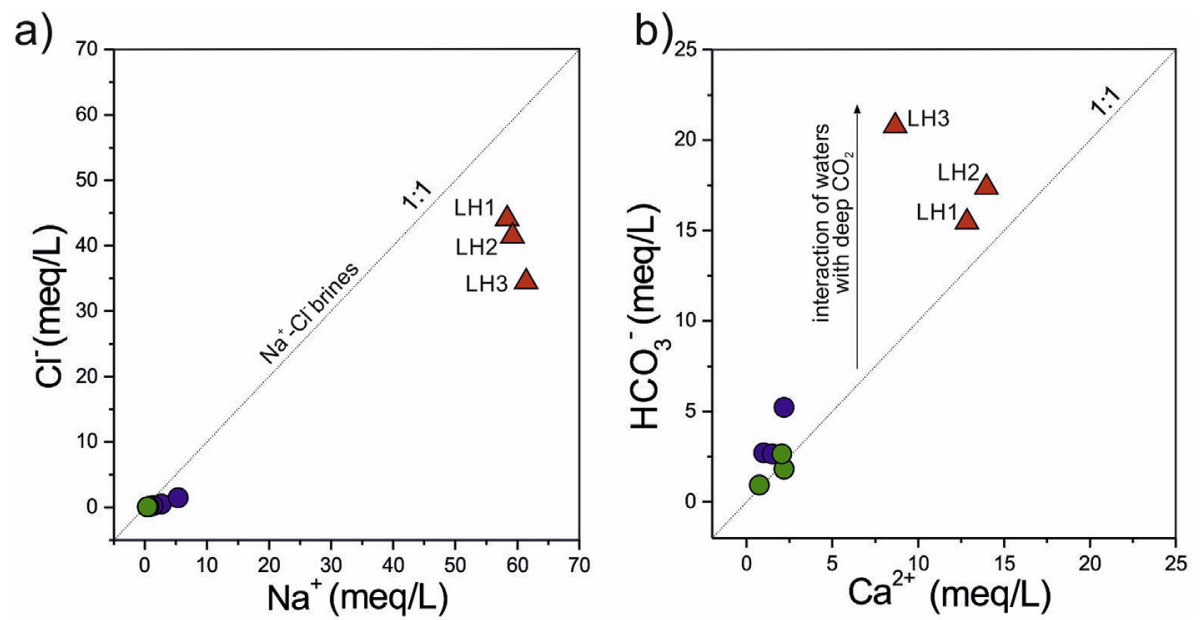

Fig. 5. (a) $\mathrm{Cl}^{-}$vs. $\mathrm{Na}^{+}$, (b) $\mathrm{HCO}_{3}{ }^{-}$vs. $\mathrm{Ca}^{2+}$ binary diagrams for the cold and thermal waters from the CBC. Symbols as in Fig. 3.

particularly efficient for the $\mathrm{LH} 3$ sample having a $\left(\mathrm{HCO}_{3}{ }^{-}+\mathrm{CO}_{3}{ }^{2-}\right)$ / $\left(\mathrm{Ca}^{2+}\right.$ ) mol-ratio of 2.4 (Fig. 5b). Travertine precipitation (Mors et al., $2016)$ is likely the cause of the $\left(\mathrm{SO}_{4}{ }^{2-}\right) /\left(\mathrm{Ca}^{2+}+\mathrm{Mg}^{2+}\right)$ mol-ratio $>1$.

The $\mathrm{B} / \mathrm{Cl}^{-}$ratios (between 0.01 and 0.02 ), lower than those typically found in fluids from geothermal systems (e.g. Giggenbach, 1991), are in the range of those characterized by heated aqueous solutions in contact with rhyolite (Ellis and Mahon, 1964, 1967; Giggenbach, 1995). Furthermore, the relatively high $\mathrm{Cl}$ and $\mathrm{B}$ contents suggest the addition of these two elements possibly through absorption of low $\mathrm{B} / \mathrm{Cl}$ magmatic vapors (Giggenbach, 1991, Fig. 6).

The cold waters pertaining to groups 2 and 3 are related to a shallow, short-live circulation source, as indicated by their low TDS contents and outlet temperatures (Table 1). However, different processes are proposed to explain their chemical composition accordingly both the geological framework and the location of the samples (Fig. 1). The $\mathrm{Na}^{+}\left(\mathrm{K}^{+}\right)-\mathrm{HCO}_{3}{ }^{-}$composition of the cold waters from El Médano area (Group 2) was probably caused by low-temperature alteration of glass contained in the alkali-rich volcanic rocks, the latter being extensively present in the area (Arnosio et al., 2008; Báez et al., 2015). This process involves considerable hydrogen exchange for $\mathrm{Na}^{+}$and $\mathrm{K}^{+}$ ions, with little variation in other major- or trace-element contents (Cerling et al., 1985). The relatively high $\mathrm{SO}_{4}{ }^{2-}$ content shown by the EM1 sample (Fig. 3c) is likely due to the dissolution of $\mathrm{H}_{2} \mathrm{~S}$-bearing

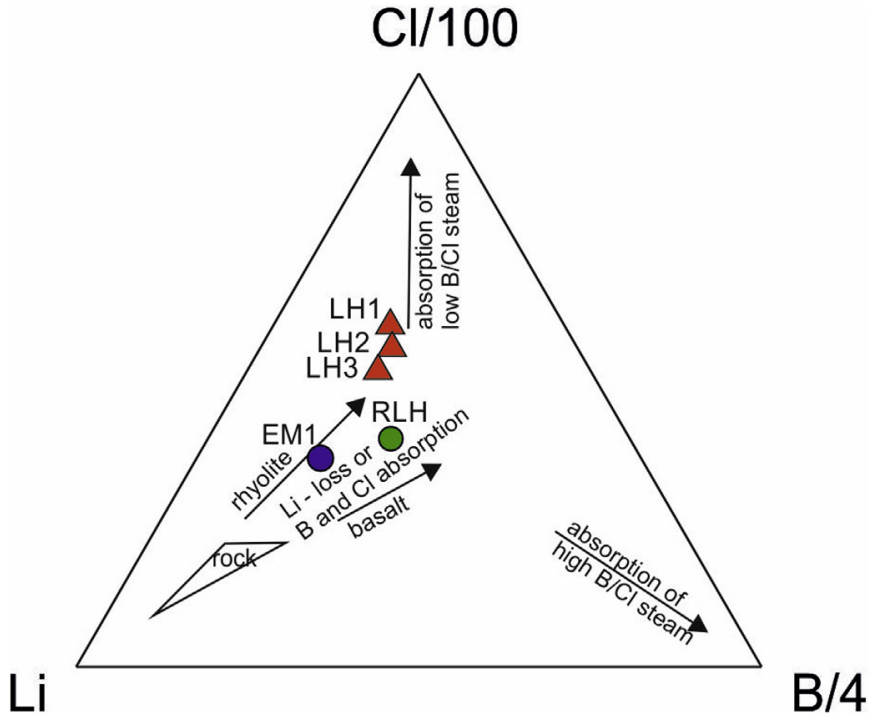

Fig. 6. $\mathrm{Cl}^{-} / 100, \mathrm{Li}^{+}, \mathrm{B} / 4$ ternary diagram (Giggenbach, 1991) for the cold and thermal waters from the CBC. Symbols as in Fig. 3. gases phase into the shallow aquifer, as also suggested by both its location near the caldera border (Fig. 1) and the relatively high $\mathrm{CO}_{2}$ content in the dissolved gases (Table 3). On the other hand, an incipient oxidation of sulfur-bearing minerals (e.g. pyrite) affecting the hydrothermal altered rocks of LHVC (Ricci et al., 1999) could also explain its $\mathrm{SO}_{4}{ }^{2-}$ content. However, it is likely that this process is acting more effectively in the CBVF1 and CBVF2 (Group 3) cold springs from the western sector of the caldera (Fig. 3c), where strongly altered rocks of the LHVC occur.

\subsection{Origin of gases}

The CBa fumarole shows the typical features of hydrothermal fluids, as follows: i) dominant water vapor, ii) occurrence of $\mathrm{H}_{2} \mathrm{~S}, \mathrm{CH}_{4}$ and $\mathrm{H}_{2}$ at significant concentrations and iii) lack of magmatic gases $\left(\mathrm{SO}_{2}, \mathrm{HCl}\right.$ and HF). The relatively high $\mathrm{N}_{2} / \mathrm{Ar}$ ratio, i.e. higher than that of air (Fig. 7a; Giggenbach, 1992) indicates the presence of extra-atmospheric $\mathrm{N}_{2}$, likely from sediments overlying the subducted slab which can produce $\mathrm{N}_{2} / \mathrm{Ar}$ ratios up to 2000 (Matsuo et al., 1978; Giggenbach, 1997b; Sano et al., 2001). The $\mathrm{N}_{2}$ excess $/{ }^{3} \mathrm{He}$ ratios, between $1.43 \times 10^{7}$ and $5.5 \times 10^{9}$ (Table 4 ), are consistent with this deep origin for $\mathrm{N}_{2}$ being in the range commonly found in gases discharging from arc volcanoes (Snyder et al., 2003).

The LH1, LH2 and LH3 bubbling pools and the EM1 dissolved gas had $\mathrm{N}_{2}$ /Ar ratios consistent with that of air-saturated water (ASW) (Fig. 7a). According to Fig. 7a, He seems to be mostly atmospheric. However, the relatively high $\mathrm{He} / \mathrm{Ne}$ ratios measured in these samples (i.e. more than an order of magnitude higher than that of air; Table 4), imply a significant extra-atmospheric He source. In fact, the Rc/Ra values (Table 4; Fig. 7b), are consistent with those found in gases from the Andean Volcanic Arc (from 0.92 to 5.52; e.g. Hoke et al., 1994; Tassi et al., 2010; Capaccioni et al., 2011), which are lower than the typical values found in other volcanic arcs (between 5 and 8; Poreda and Craig, 1989a,b; Hilton et al., 1993; Giggenbach and Poreda, 1993). Considering that the $\mathrm{R} / \mathrm{Ra}$ ratios of gases from subduction zones are mainly controlled by the crustal thickness, being related to the residence time of fluids in the ${ }^{4} \mathrm{He}$-rich crust (e.g. Hilton et al., 1993; Fischer and Chiodini, 2015), the Rc/Ra values of the CBC samples are consistent with the abnormally thick crust of the Southern Puna (Heit et al., 2014), fitting well with those values from hydrothermal systems from the Central Andean Volcanic Zone (e.g. Tassi et al., 2010; Benavente et al., 2016; Peralta Arnold et al., 2017). As far as the $\delta^{13} \mathrm{C}-\mathrm{CO}_{2}$ values are concerned, they are consistent with those of mantle $\mathrm{CO}_{2}$ (Rollinson, 1993; Sano and Marty, 1995; Hoefs, 1997; Ohmoto and Goldhaber, 1997). However, the $\mathrm{CO}_{2} /{ }^{3} \mathrm{He}$ ratios (up to $2.26 \times 10^{11}$; Table 4; Fig. 7c) are two orders of magnitude higher than 
a)

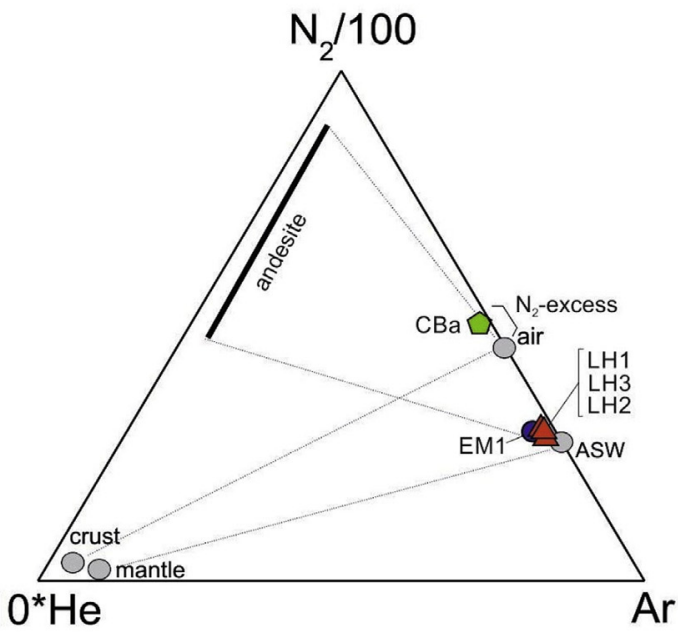

b)

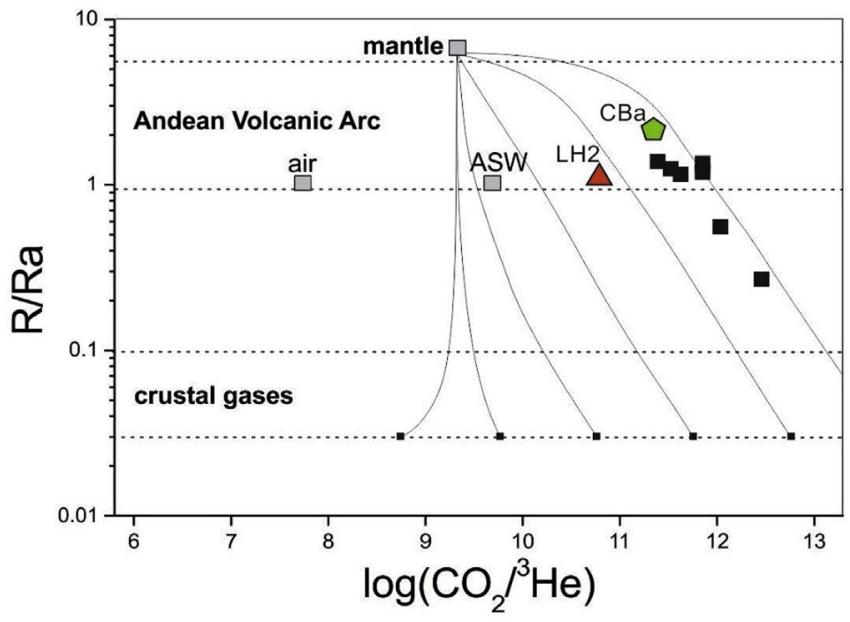

c)

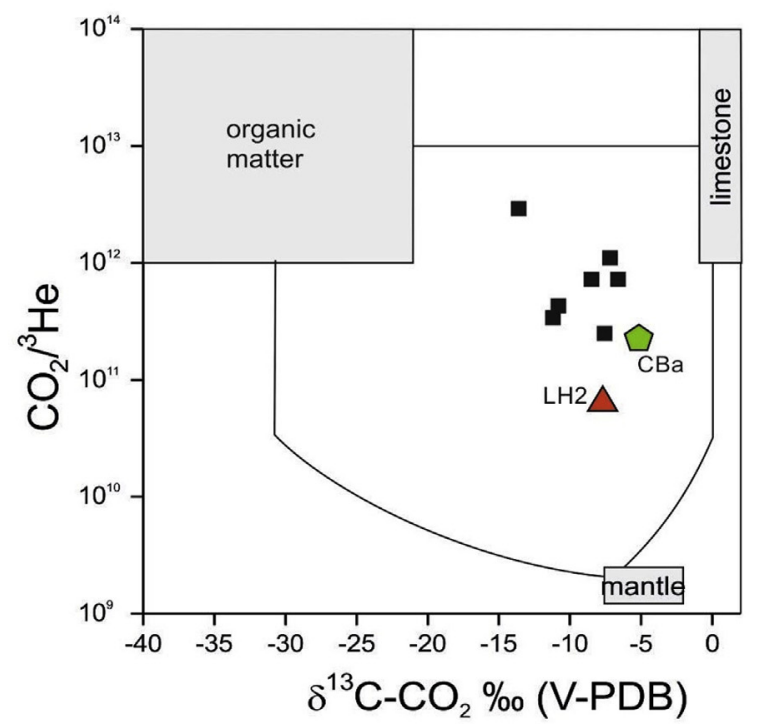

the mantle values $\left(\sim 1.2 \times 10^{9}\right.$; Marty and Jambon, 1987), suggesting that $\mathrm{CO}_{2}$ derived from a mixture between MORB-related gases and gases from a crustal source such as i) degradation of organic matter and/or ii) subduction of C-bearing material. The first option is unlikely
Fig. 7. (a) He- $\mathrm{N}_{2}$-Ar ternary diagram for the gases from the Cerro Blanco caldera. Concentrations are in $\mathrm{mmol} / \mathrm{mol}$, (b) $\mathrm{R} / \mathrm{Ra}$ vs. $\log \left(\mathrm{CO}_{2} /{ }^{3} \mathrm{He}\right)$ binary diagram for the gases from the Cerro Blanco caldera. Mixing curves between a mantle gas end-member and a crustal gas end-member with radiogenic helium and variable $\mathrm{CO}_{2} /{ }^{3} \mathrm{He}$ ratios are shown. Between dashed lines, average values for Andean Volcanic Arc (Hoke et al., 1994) and crustal gases (Hilton et al., 2002), (c) $\mathrm{CO}_{2} /{ }^{3} \mathrm{He}$ vs. $\delta^{13} \mathrm{C}_{-} \mathrm{CO}_{2} \%$ binary diagram for the gases from the Cerro Blanco Caldera. Isotopic values from others geothermal systems in the Puna plateau (Peralta Arnold et al., 2017) are shown for comparison. Symbols are: red triangle: bubbling gases from Los Hornitos area; green circle: dissolved gases from El Médano area; green pentagon: fumarolic gas sample; black square: data from Peralta Arnold et al., (2017). (For interpretation of the references to color in this figure legend, the reader is referred to the Web version of this article.)

Table 4

$\delta^{13} \mathrm{C}^{-\mathrm{CO}_{2}}$ (\%o vs. V-PDB), Rc/Ra for selected gas samples; $\mathrm{CO}_{2} /{ }^{3} \mathrm{He}$ and $\mathrm{N}_{2}$ excess/ ${ }^{3} \mathrm{He}$ ratios. n.a.: not analyzed.

\begin{tabular}{llllll}
\hline ID & Rc/Ra & $\mathrm{He} / \mathrm{Ne}$ & $\delta^{13} \mathrm{C}-\mathrm{CO}_{2}$ & $\mathrm{CO}_{2} /{ }^{3} \mathrm{He}$ & $\mathrm{N}_{2}$ excess $/{ }^{3} \mathrm{He}$ \\
\hline CBa & 2.16 & 7.8 & -5.23 & $2.26 \times 10^{11}$ & $5.5 \times 10^{9}$ \\
LH1 & n.a. & 6.1 & -7.48 & n.a. & n.a. \\
LH2 & 1.11 & 6.1 & -7.77 & $6.31 \times 10^{10}$ & $1.43 \times 10^{7}$ \\
LH3 & n.a. & 5.4 & -9.56 & n.a. & n.a. \\
EM1 & n.a. & 8.7 & -9.12 & n.a. & n.a. \\
\hline
\end{tabular}

since organic $\mathrm{CO}_{2}$ is characterized by $\delta^{13} \mathrm{C}-\mathrm{CO}_{2}$ values $\leq-20 \%$ vs. VPDB (Hoefs, 2008), i.e. too negative in comparison with those of the $\mathrm{CBC}$ gases. On the other hand, a significant contribution of $\mathrm{CO}_{2}$ from reactions involving C-bearing material, which generally shows $\delta^{13} \mathrm{C}-\mathrm{CO}_{2}$ values between -2 and $+2 \%$ vs. V-PDB (Rollinson, 1993), seems to be excluded by the more negative $\mathrm{CBC}$ carbon signature. Notwithstanding, secondary processes, such as calcite precipitation (Barry et al., 2019) and ${ }^{13} \mathrm{C}-{ }^{12} \mathrm{C}$-fractionation, the latter being related to the dissolution of gaseous $\mathrm{CO}_{2}$ in the hydrothermal aquifer (Gilfillan et al., 2009), may explain a ${ }^{12} \mathrm{C}$-enrichment in the $\mathrm{CBC}$ gases. In agreement with this hypothesis, extreme ${ }^{13} \mathrm{C}$ enrichments (up to $+13 \%$ V-PDB) were found in primary calcite and aragonite precipitates from high-altitude lakes in the southern Andean Altiplano (Valero-Garcés et al., 1999). It is important to highlight that, in the geodynamic context of the Southern Puna, the genesis of silicic magmas commonly involves significant contribution of partial melting of the crust (e.g. Caffe et al., 2002; Kay et al., 2011). Therefore, the origin of $\mathrm{CO}_{2}$ in the $\mathrm{CBC}$ gases is likely related to degassing crust-contaminated magmas, subsequently affected by secondary processes.

\subsection{Temperature estimations of the hydrothermal reservoir}

Considering the chemical equilibria in the Na-K-Mg system, commonly adopted for aqueous solutions interacting with the typical authigenic mineral assemblage (including Na- and K-feldspars, K-micas, chlorite and silica), the LH1-LH3 waters, which show the highest $\mathrm{Cl}^{-}$ concentrations, point to temperatures of $235-237^{\circ} \mathrm{C}$ (Fig. 8a). Similar temperatures are indicated by the $\left(10 \mathrm{~K}^{+} /\left[10 \mathrm{~K}^{+}+\mathrm{Na}^{+}\right]\right.$vs. $10 \mathrm{Mg}^{2+} /$ $\left[10 \mathrm{Mg}^{2+}+\mathrm{Ca}^{2+}\right]$ ) geothermometer (Fig. 8b), where the effect of $\mathrm{Ca}^{2+}$ in the calculations and the mineral assemblage were considered (Chiodini et al., 1995). Notwithstanding the consistency of the two independent geothermometers, such calculated temperatures should be considered with severe caution due to the incomplete maturity of these CBC waters that is also indicated by the lack of any isotopic shift in the $\delta^{18} \mathrm{O} \%$ (Fig. 4).

Water-rock exchange reactions involving $\mathrm{Mg}$ proceed relatively fast at low temperatures, thus the $\mathrm{K} / \mathrm{VMg}$ and $\mathrm{Li} / \mathrm{VMg}$ ratios appear to be good geothermometers for low maturity waters (Fournier, 1991; Inguaggiato et al., 2000). The temperatures estimated on the basis of the for $\mathrm{K} / \mathrm{VMg}$ and $\mathrm{Li} / \mathrm{VMg}$ ratios, between 121 and $127^{\circ} \mathrm{C}$, and 137 and 
a)

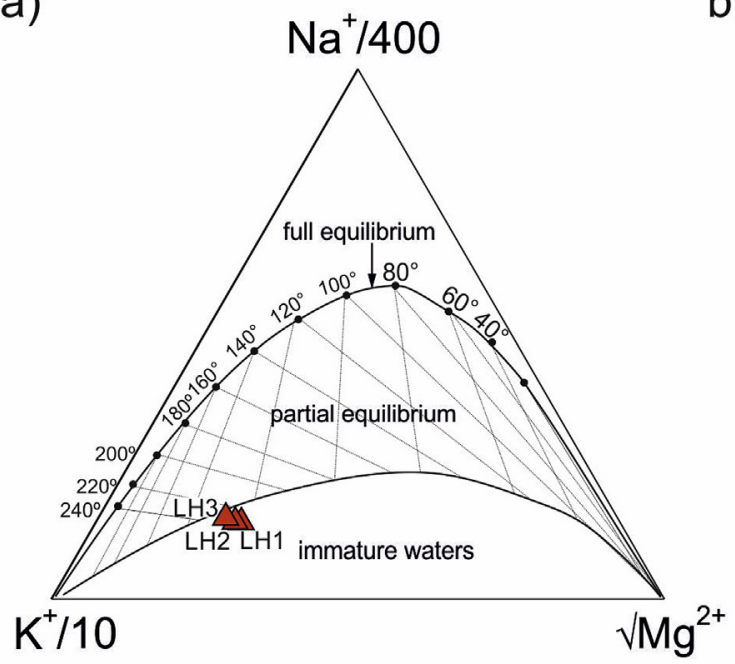

b)

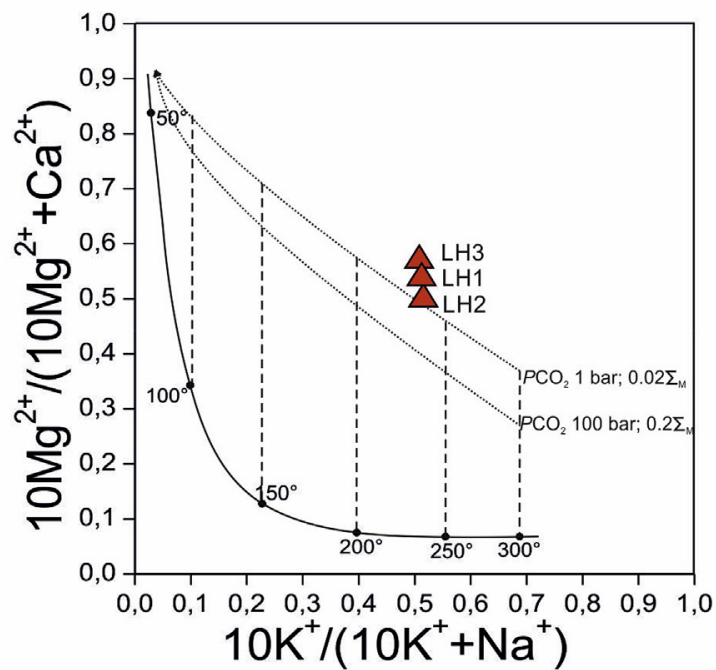

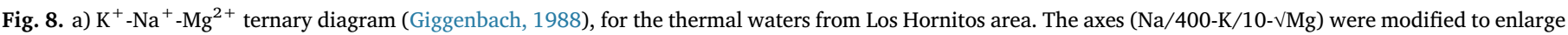

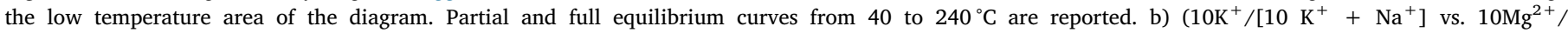

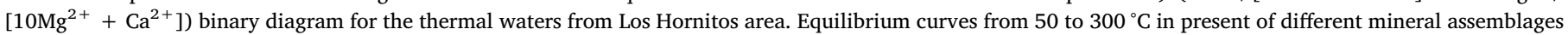
(Giggenbach, 1988; Chiodini et al., 1995) are reported.

$144^{\circ} \mathrm{C}$, are actually lower than those calculated in the $\mathrm{Na}-\mathrm{K}-\mathrm{Mg}-\mathrm{Ca}$ system (Table 5) and likely reflect equilibria attained during the fluid uprising toward the surface. Saturation index (SI = log AP/Ksp; where AP: ion activity product and Ksp: solubility product) values for various mineralogical species from the emergence temperature $42.7-300{ }^{\circ} \mathrm{C}$ were computed using the PHREEQC v. 3.2 (Parkhurst and Appelo, 1999) software package (llnl: Lawrence Livermore National Laboratory database) for the LH3 water sample (the sample that most closely approximates to the partial equilibrium line; Fig. 8a). Minerals (except for Analcime, Prhenite, Wairakite and Clinozoisite) seem to attain the equilibrium at temperatures ranging from 94 to $135^{\circ} \mathrm{C}$ (Fig. 9), which are consistent with those estimated by using the kinetically fast geothermometers.

Concentration of $\mathrm{SiO}_{2}$ in the liquid phase depends on the dissolution of different silica mineral in correspondence with temperature. At relatively high temperatures $\left(>200^{\circ} \mathrm{C}\right.$ ), silica contents appear to be governed by equilibrium with quartz, while at lower temperatures with its microcrystalline form, chalcedony. Temperature estimations carried out using the silica geothermometers proposed by Fournier (1973) are listed in Table 5. The equilibrium temperatures obtained adopting quartz as the main silica mineral ranged between 139 and $159^{\circ} \mathrm{C}$, which are values too low for a correct application of this geothermometer. On the other hand, the chalcedony geothermometer, i.e. the most appropriate in this range of temperatures, provides estimated temperatures from 112 to $135^{\circ} \mathrm{C}$, in agreement with the indication of the $\mathrm{K} / \mathrm{VMg}$ and $\mathrm{Li} / \mathrm{VMg}$ values (Table 5) and the SI of the mineralogical species (Fig. 9).

The $\mathrm{CO}_{2}$ geothermometer proposed by Giggenbach and Goguel (1989) assumes that $\mathrm{P}_{\mathrm{CO} 2}$ is controlled by interactions with crustal rocks, whereas further geothermometric estimations can be carried out based on the dependence of $\mathrm{H}_{2}$ fugacity on temperature (Giggenbach, 1987). To avoid possible problems related to the use of univariant reactions, Giggenbach (1991) proposed the use of $\mathrm{CO}_{2} / \mathrm{Ar}$ and $\mathrm{H}_{2} / \mathrm{Ar}$ ratios, assuming that Ar has a meteoric origin.

Considering that hydrothermal fluids are $\mathrm{O}_{2}$-free, to prevent the effect of possible air contamination at the surface, Ar* values were computed, as follows:

$\mathrm{Ar}^{*}=\mathrm{Ar}-\mathrm{O}_{2} / 22$

where the $\mathrm{O}_{2} / 22$ ratio is the minimum Ar concentration from air contamination. The dependence of $\mathrm{H}_{2}$ on $\mathrm{R}_{\mathrm{H}}$ in the two phases can be expressed, as follows:

$\log \left(\mathrm{H}_{2} / \mathrm{Ar}^{*}\right)_{\mathrm{V}}=\mathrm{R}_{\mathrm{H}}+6.52-\log \left(\mathrm{B}_{\mathrm{Ar}}\right)$

$\log \left(\mathrm{H}_{2} / \mathrm{Ar}^{*}\right)_{\mathrm{L}}=\mathrm{R}_{\mathrm{H}}+6.52-\log \left(\mathrm{B}_{\mathrm{H} 2}\right)$

where $\mathrm{B}_{\mathrm{H} 2}$ and $\mathrm{B}_{\mathrm{Ar}}$ are the vapor/liquid distribution coefficient of $\mathrm{H}_{2}$ and $\mathrm{Ar}$, respectively.

At redox conditions controlled by the D'Amore and Panichi (1980) redox buffer (DP), the dependence of $\mathrm{CO}_{2} / \mathrm{Ar}^{*}$ ratios on temperature is given by:

$\log \left(\mathrm{CO}_{2} / \mathrm{Ar}^{*}\right)_{\mathrm{V}}=\log \left(\mathrm{PCO}_{2}\right)-5.51+2048 / \mathrm{T}+6.52-\log \left(\mathrm{B}_{\mathrm{Ar}}\right)$
$\log \left(\mathrm{CO}_{2} / \mathrm{Ar}^{*}\right)_{\mathrm{L}}=\log \left(\mathrm{PCO}_{2}\right)-5.51+2048 / \mathrm{T}+6.52-\log \left(\mathrm{B}_{\mathrm{CO} 2}\right)$

where $\mathrm{T}$ is in $\mathrm{K}$ and $\mathrm{B}_{\mathrm{CO} 2}$ is the vapor/liquid distribution coefficient of $\mathrm{CO}_{2}$ and the dependence of $\log \left(\mathrm{PCO}_{2}\right)$ on temperature is given by:

$\log \left(P \mathrm{CO}_{2}\right)=0.0168 \times \mathrm{t}-3.78$

where $t$ is the temperature in Celsius. The combination of the $\mathrm{CO}_{2} / \mathrm{Ar}^{*}$ and $\mathrm{H}_{2} / \mathrm{Ar}^{*}$ geothermometers from 150 to $350{ }^{\circ} \mathrm{C}$ is graphically displayed in Fig. 10. Both the fumarolic gas sample (CBa) and the LH2 bubbling gas plot below the full equilibrium line with the liquid phase suggesting that they are affected by secondary processes such as: i) $\mathrm{CO}_{2}$ dissolution, as also invoked to explain the measured $\delta^{13} \mathrm{C}-\mathrm{CO}_{2}$ values, (ii) $\mathrm{H}_{2}$ consumption at shallow deep, where the occurrence of air contamination causes oxidizing conditions and (iii) Ar addition. Thus, deep temperature estimations by using these geothermometric approach are not reliable.

\subsection{Geochemical conceptual model}

Based on the available geochemical, structural, and hydrogeological data, the following conceptual model is proposed, integrated in the schematic cross section of Fig. 11. A deep $\mathrm{Na}^{+}-\mathrm{Cl}^{-}\left(\mathrm{HCO}_{3}\right)^{-}$aquifer, which represents the hydrothermal reservoir with temperatures of at least $135^{\circ} \mathrm{C}$ (based on silica contents), is possibly hosted into the precaldera basement rocks (Bm; mainly in the Miocene volcanic rocks of the La Hoyada volcanic Complex; Fig. 11b), whose permeability is likely caused by the intense fracturing generated during the caldera collapse. The unconsolidated very fine-grained pyroclastic fall deposits of the Cerro Blanco ignimbrite (CBI), characterized by a low permeability, would act as the cap-rock of the hydrothermal system. In 


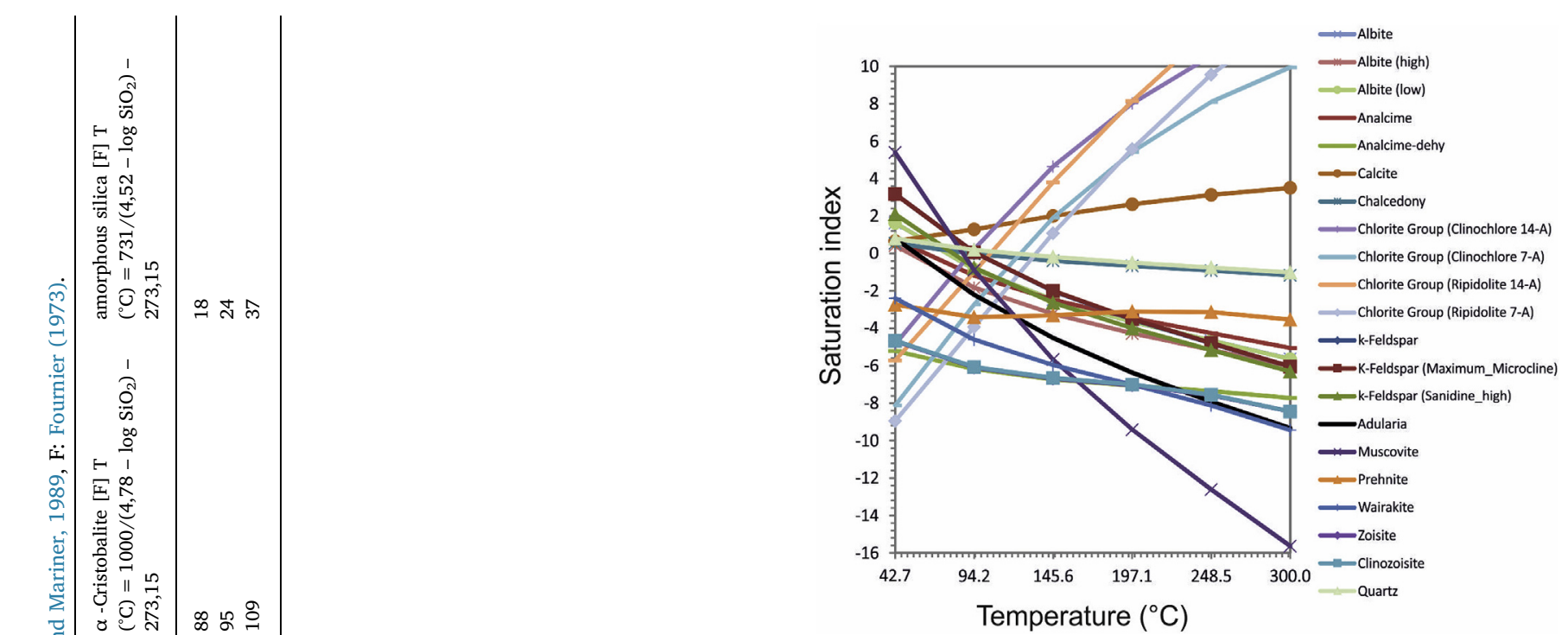

Fig. 9. Temperature $\left({ }^{\circ} \mathrm{C}\right)$ estimated for the LH3 thermal water by using the saturation indexes for various mineralogical species between the emergence temperature $42.7-300{ }^{\circ} \mathrm{C}$.

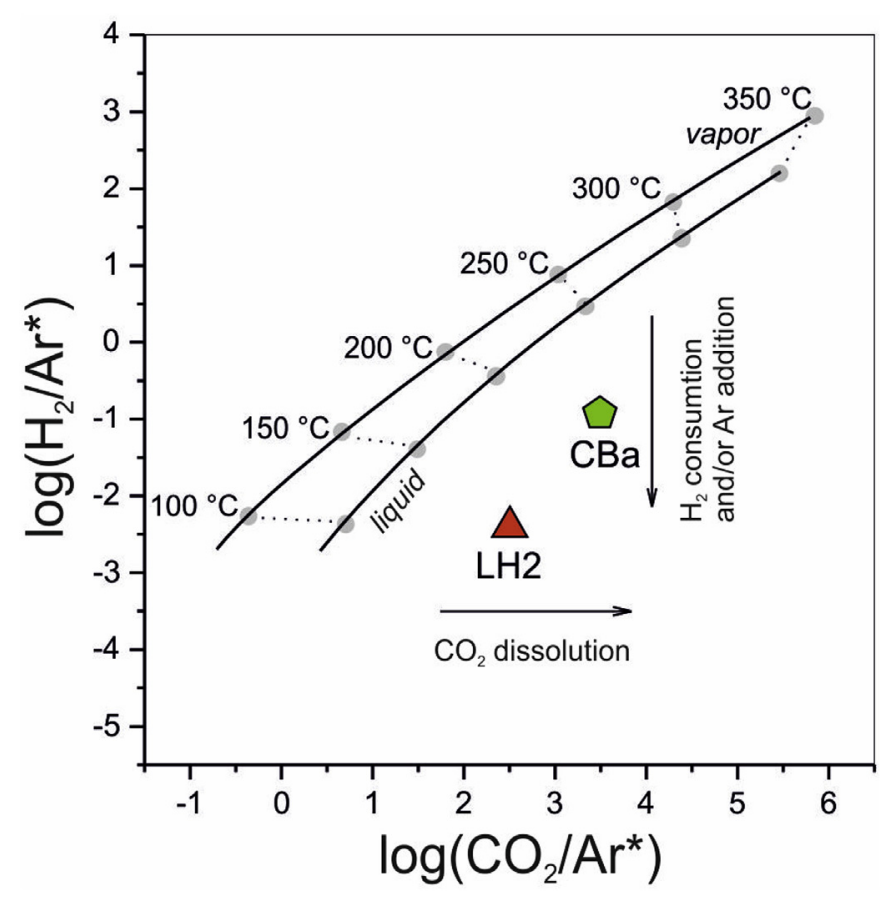

Fig. 10. $\log \left(\mathrm{H}_{2} /{ }^{*} \mathrm{Ar}\right)$ vs. $\log \left(\mathrm{CO}_{2} /{ }^{*} \mathrm{Ar}\right)$ binary diagram for bubbling and fumarolic gases the Cerro Blanco caldera. Solid lines refer to equilbria in the vapor and liquid phases controlled by the GT redox buffer system at temperatures from 150 to $350{ }^{\circ} \mathrm{C}$ (Giggenbach, 1987).

addition, the hydrothermal alteration of the basal section of the CBI could further decrease the low porosity of this layer. The existence of phreatic eruption breccias in the surrounding area of the geothermal fumaroles (Fig. 2a) requires that the hydrothermal aquifer may suffer over-pressurization, proving the effectiveness of the $\mathrm{CBI}$ as sealing rock. In addition, the presence of pre-caldera basement blocks into the breccias supports the idea that the former could act as the main reservoir for hydrothermal fluids. The occurrence of sinter deposits in the vicinity of the fumaroles implies a water source at temperatures higher than $180^{\circ} \mathrm{C}$ in the past and an efficient fluid uprising from the reservoir to the surface, likely favored by the NE-SW fault system. The isotopic data $\left(\delta^{18} \mathrm{O}\right.$ and $\mathrm{D}$; Fig. 4) indicate a meteoric recharge of the 


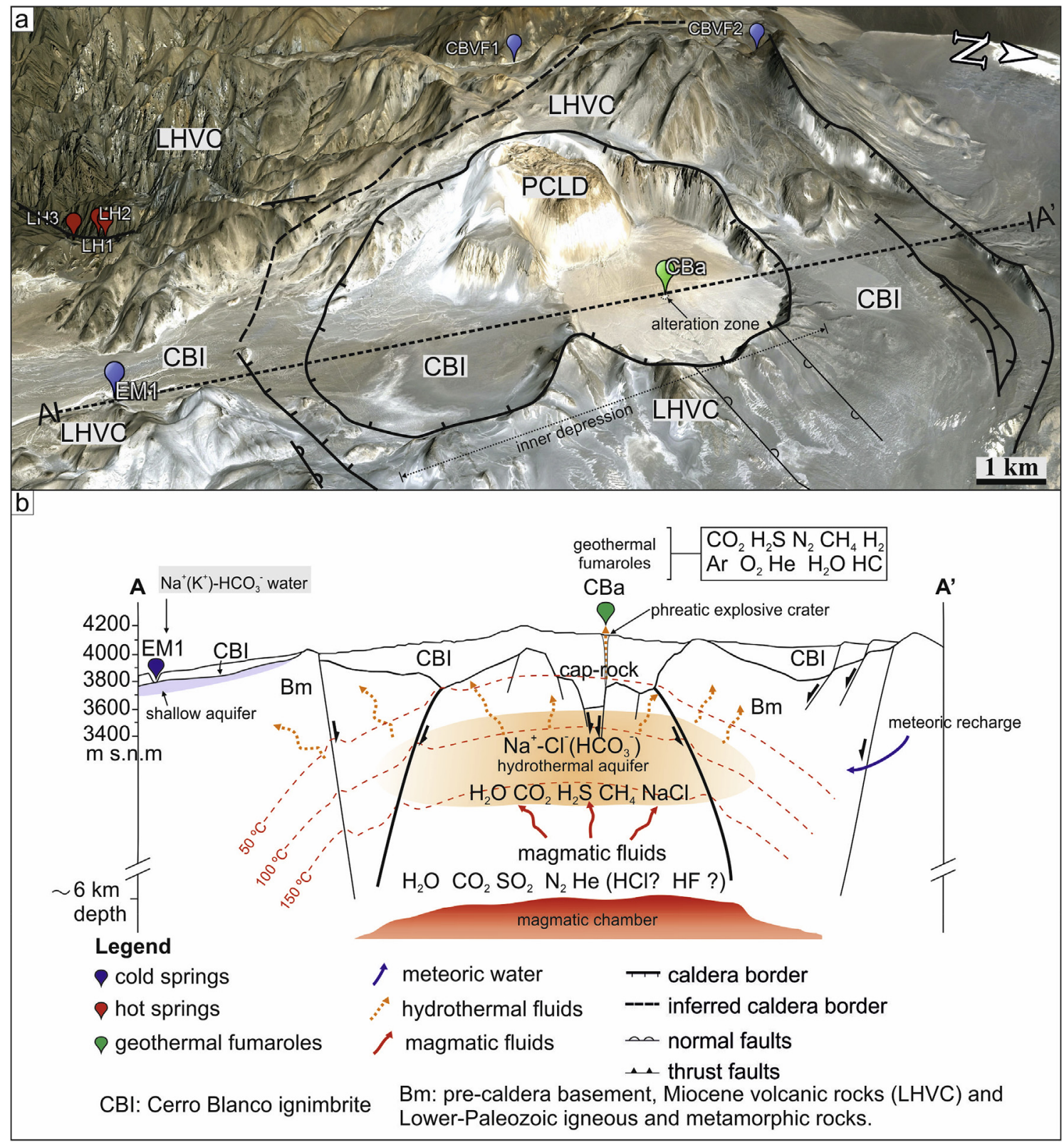

Fig. 11. (a) 3D-Google Earth image of the Cerro Blanco Caldera where the schematic cross section A-A' (b), and some fluid discharge points are indicated. (b) Geochemical conceptual model of the Cerro Blanco Geothermal System in a schematic cross section oriented SE-NW (A-A') (cross section from Báez et al., 2015). The trace of the schematic cross section A-A' in shown in Fig. 1a. PCLD: post-caldera lava domes.

hydrothermal reservoir. According to the $\delta^{18} \mathrm{O}-\mathrm{H}_{2} \mathrm{O}$ vertical gradient $(-2.8 \% 0 / \mathrm{km}$, estimated with calculations based on the chemistry of the cold springs and stream waters that are plotted on the LMWL), the meteoric recharge is likely located at an altitude of $4100-4300 \mathrm{~m}$ a.s.l., suggesting that the sectors surrounding the $\mathrm{CBC}$, mainly towards the $\mathrm{W}$ and NW where large outcrops of the pre-caldera basement exist, are the sites where meteoric precipitations infiltrate and supply the hydrothermal reservoir.

Fluids from the degassing magma chamber contribute significantly ( $\sim 39 \%$ of primordial helium, considering a R/Ra value of 5.5 for local mantle; Hoke et al., 1994) to the hydrothermal reservoir. Fluids from the fumaroles showed the typical features of hydrothermal fluids: dominant water vapor and significant concentrations of $\mathrm{H}_{2} \mathrm{~S}, \mathrm{CH}_{4}$ and $\mathrm{H}_{2}$. The occurrence of cold springs in the El Médano area (EM1) with $\mathrm{Na}^{+}-\mathrm{HCO}_{3}{ }^{-}\left(\mathrm{SO}_{4}{ }^{2-}\right)$ composition and low TDS content (Table 1) suggests the interaction between the deep hydrothermal fluids with the water table (Fig. 11b), which in calderas is usually close to the ground surface due to the relatively small topographic gradient (Hurwitz et al., 2003, 2007).

A fault-controlled hydraulic connection between the hot springs and the hydrothermal reservoir is proposed for the Los Hornitos area. Fig. $1 \mathrm{a}$ and $\mathrm{b}$ highlights that the NNE-SSW tectonic structure that uplift Los Colorados range towards north, cutting both the pre-caldera basement and the overlying volcanic-sedimentary sequence, could act as a preferential pathway for lateral advection of hydrothermal fluids allowing the emergence of Los Hornitos hot springs towards the south. The low $\mathrm{Na} / \mathrm{K}$ ratios $\left({ }^{<} 15\right)$ in these thermal waters indicate that have reached the surface rapidly, and are therefore associated with highly permeable zones (Nicholson, 1993).

Considering: (i) an average depth of the reservoir rock of $\sim 1200 \mathrm{~m}$ estimated by gravimetry studies (Di Filippo et al., 2008, cross section from Báez et al., 2015), (ii) an average surface water temperature of $\sim 10^{\circ} \mathrm{C}$ (Tchilinguirian and Olivera, 2014) and (iii) the calculated reservoir temperatures using the silica content $\left(135^{\circ} \mathrm{C}\right)$, the local 
geothermal gradient for the $\mathrm{CBC}$ would be around $\sim 104^{\circ} \mathrm{C} / \mathrm{km}$. Such a high geothermal gradient resembles those proposed for caldera-hosted hydrothermal systems with acidic compositions (Wood, 1995) and would be a consequence of the high heat flow generated by the emplacement (during Holocene) of a magmatic chamber in the upper levels of the crust ( $\sim 6 \mathrm{~km}$ depth; López, 2016).

\subsection{Estimated geothermal potential}

The estimation of the geothermal potential is usually done by applying the Volume Method (Muffler and Cataldi, 1978; Doveri et al., 2010), which is based on the definition of a reservoir volume, with an associated porosity and an average fluid temperature; given by:

$\mathrm{E}=\mathrm{Er}+\mathrm{Ef}=\left[(1-\varphi) \times \rho r \times \mathrm{Cr} \times \mathrm{A} \times \mathrm{Z}\left(\mathrm{T}-\mathrm{T}_{0}\right)\right]$

$$
+\left[\varphi \times \rho f \times C f \times A \times Z\left(T-T_{0}\right)\right]
$$

where $\mathrm{Er}$ is the heat stored in the solid rocks and $\mathrm{Ef}$ in the fluid phase.

The area considered for the calculations $\left(A=39 \mathrm{~km}^{2}\right)$ coincides with the inner depression of the CBC (Fig. 11a), where the collapse of pre-caldera blocks was mainly focused (Báez et al., 2015) and currently records the higher subsidence rates (Brunori et al., 2013; López, 2016). For the estimations of the geothermal potential, two possible thicknesses were contemplated for the reservoir $\left(Z_{\min }=500 \mathrm{~m}\right.$ and $\mathrm{Z}_{\max }=1000 \mathrm{~m}$, both considered as conservative values; e.g. Sorey et al., 1991; Giordano et al., 2014), and the conservative average temperature estimated using the silica content $\left(135^{\circ} \mathrm{C}\right)$. Considering a rock density of $2650 \mathrm{~kg} / \mathrm{m}^{3}$ ( $\rho r$ ) with an average effective porosity of 0.05 ( $\varphi$; e.g. Zarrouk and Simiyu, 2013), $850 \mathrm{~J} / \mathrm{kg}$ for the rock specific heat $(\mathrm{Cr}), 4270 \mathrm{~J} / \mathrm{kg}$ for water specific heat $(\mathrm{Cf})$ and a $\mathrm{T}_{0}$ of $10^{\circ} \mathrm{C}$ as air temperature, the following results are obtained:

$\mathrm{Er}_{\min }=5.22 * 10^{18} \mathrm{~J} \quad \mathrm{Er}_{\max }=1.04 * 10^{19} \mathrm{~J}$

$\mathrm{Ef}_{\min }=4.85 * 10^{17} \mathrm{~J} \quad \mathrm{Ef}_{\max }=9.70 * 10^{17} \mathrm{~J}$

It is important to highlight that the estimation of the geothermal potential was made adopting all conservative values. In this sense and taken into account the geological framework, the results are probably underestimated.

\section{Conclusions}

The geochemical investigation presented in this work provides the baseline of the chemical and isotope composition of the superficial and groundwaters present in the Cerro Blanco caldera-hosted hydrothermal system. The main hydrothermal reservoir has a $\mathrm{Na}^{+}-\mathrm{Cl}^{-}\left(\mathrm{HCO}_{3}\right)^{-}$composition with temperatures of at least $135^{\circ} \mathrm{C}$. Considering the high geothermal gradient resulting for this area $\left(\sim 104^{\circ} \mathrm{C} / \mathrm{km}\right)$ and the relatively high fraction of mantle $\mathrm{He}(\sim 39 \%)$, this aquifer likely receives inputs of magmatic fluids from the degassing magma chamber. Both the scarcely presence of superficial thermal manifestations associated with the CBGS and the occurrence of an efficient cap-rock likely contribute to minimize the loss of thermal energy from the reservoir (Goff and Janik, 2000; Todesco and Giordano, 2010). The preliminary geothermal potential at $\mathrm{CBC}$ has been evaluated with the Volume Method, calculating up to $\mathrm{E}=11.4 * 10^{18} \mathrm{~J}$. Hence, this system is a promising target to continue geothermal investigations.

Up to date, the only geothermal target considered of interest to continue geothermal investigations in the northwestern Argentina was the Tuzgle-Tocomar geothermal system (Giordano et al., 2013, 2016; Norini et al., 2014; Filipovich et al., 2017). In this sense, the present investigation expands the frontiers of geothermal research in northwestern Argentina, unveiling a promising geothermal system for this region. The results here presented and discussed could constitute the necessary base of knowledge for further accurate assessment of the geothermal potential and ultimately the implementation of the geothermal resource as a viable energy alternative for small localities or mining facilities (e.g. El Peñón and Las Papas localities, La Hoyada mining district, etc.), isolated from the National Interconnected System due to their remote localization. Geophysical studies are required to confirm and improve the proposed conceptual model.

\section{Acknowledgements}

This work has been funded by the project PICT 2015-0540: "Estimación del potencial geotérmico del área de la caldera del Cerro Blanco (Puna Austral) a través de mediciones del flujo de $\mathrm{CO}_{2}$ difuso y geoquímica de fluidos (2016-2018)", MINCYT, directed by Agostina Chiodi and Progetto AR00197 di Grande Rilevanza: "Sviluppo dei sistemi sostenibile geotermici Associati della ai sistemivulcanici Puna di nelle Salta Province (2014-2016)", directed by Guido Giordano and Jose G. Viramonte. INENCO, UNSa-CONICET are thanked for the financial and lodging assistance. We thanks Analía Bohemo and Lidia Peñaloza (Cátedra de Química Analítica, UNSa) for precious support in the laboratory and E. Calvi (CNR-IGG, Pisa) for kindly analyzing the ${ }^{13} \mathrm{C} /{ }^{12} \mathrm{C}$ ratios in $\mathrm{CO}_{2}$.

\section{Appendix A. Supplementary data}

Supplementary data to this article can be found online at https:// doi.org/10.1016/j.jsames.2019.102213.

\section{References}

Aiuppa, A., Avino, R., Brusca, L., Caliro, S., Chiodini, G., D'Alessandro, W., Favara, R. Federico, C., Ginevra, W., Inguaggiato, S., Longo, M., Pecoraino, G., Valenza, M., 2006. Mineral control of arsenic content in thermal waters from volcano-hosted hydrothermal systems: insights from Island of Ischia and Phlegrean Fields (Campanian Volcanic Province, Italy). Chem. Geol. 229, 313-330.

Arnosio, M., Becchio, R., Viramonte, J.G., Groppelli, G., Norini, G., Corazzato, C., 2005 Geología del Complejo Volcánico Cerro Blanco ( $26^{\circ}$ 45’ LS- 67 45’ LO), Puna Austral. In: Proceedings Geological Congress, La Plata, Argentina, pp. 851-858.

Arnosio, M., Becchio, R., Viramonte, J.G., de Silva, S., Viramonte, J.M., 2008. Geocronología e isotopía del Complejo Volcánico Cerro Blanco: un sistema de calderas cuaternario (73-12 ka) en los Andes Centrales del sur. In: $17^{\circ}$ Proceedings Geological Congress, Jujuy, Argentina, pp. 177-178.

Báez, W., Arnosio, M., Chiodi, A., Ortiz Yañes, A., Viramonte, J.G., Giordano, G., Bustos, E., 2015. Estratigrafía y evolución del Complejo Volcánico Cerro Blanco, Puna Austral, Argentina. Rev. Mex. Ciencias Geol. 1, 29-49.

Báez, W., Chiodi, A., Bustos, E., Arnosio, M., Viramonte, J.G., Giordano, G., 2017. Mecanismos de emplazamiento y destrucción de los domos lávicos asociados a la Caldera del Cerro Blanco, Puna Austral. Rev. Asoc. Geol. Argent. 74, 223-238.

Barry, P.H., de Moor, J.M., Giovannelli, D., Schrenk, M., Hummer, D.R., Lopez, T., Pratt, C., Alpízar Segura, Y., Battaglia, A., Beaudry, P., Bini, G., Cascante, M., d'Errico, G., di Carlo, M., Fattorini, D., Fullerton, K., Gazel, E., González, G., Halldórsson, S. Iacovino, K., Kulongoski, J., Manini, E., Martínez, Miller, H., Nakagawa, M., Ono, S., Patwardhan, S., Ramírez, C., Regoli, F., Smedile, F., Turner, S., Vetriani, C., Yucel, M., Ballentine, C., Fischer, T., Hilton, D., Lloyd, K., 2019. Forearc carbon sink reduces long-term volatile recycling into the mantle. Nature 568 (7753), 487.

Benavente, O., Tassi, F., Reich, M., Aguilera, F., Capecchiacci, F., Gutiérrez, F., Vaselli, O., Rizzo, A., 2016. Chemical and isotopic features of cold and thermal fluids discharged in the Southern Volcanic Zone between $32.5 \mathrm{~S}$ and $36 \mathrm{~S}$ : Insights into the physical and chemical processes controlling fluid geochemistry in geothermal systems of Central Chile. Chem. Geol. 420, 97-113.

Bencini, A., 1985. Applicabilità del metodo dell'Azometina-H alla determinazione del boro nelle acque naturali. Rendiconti Societa Italiana di Mineralogia e Petrologia 40, 311-316.

Bershaw, J., Saylor, J.E., Garzione, C.N., Leier, A., Sundell, K.E., 2016. Stable isotope variations $\left(\delta^{18} \mathrm{O}\right.$ and $\left.\delta \mathrm{D}\right)$ in modern waters across the Andean Plateau. Geochem. Cosmochim. Acta 194, 310-324.

Bertani, R., 2010. Geothermal power generation in the world, 2005-2010 Update Report. In: Proceedings World Geothermal Congress, 25-29 April, Indonesia, Bali, pp. 41.

Bustos, E., Báez, W., Norini, G., Arnosio, M., de Silva, S.L., 2019. The geological and structural evolution of the long-lived Miocene-Pleistocene La Hoyada Volcanic Complex in the geodynamic framework of the Central Andes, Argentina. J. Volcanol. Geotherm. Res (in press).

Brunori, C., Bignami, C., Stramondo, S., Bustos, E., 2013. 20 years of active deformation on volcano caldera: joint analysis of InSAR and AInSAR techniques. Int. J. Appl. Earth Obs. Geoinf. 23, 279-287.

Caffe, P.J., Trumbull, R.B., Coira, B.L., Romer, R.L., 2002. Petrogenesis of early Neogene magmatism in the northern Puna; implications for magma genesis and crustal processes in the central Andean Plateau. J. Petrol. 43 (5), 907-942.

Capaccioni, B., Aguilera, F., Tassi, F., Darrah, T., Poreda, R.J., Vaselli, O., 2011. Geochemical and isotopic evidences of magmatic inputs in the hydrothermal reservoir feeding the fumarolic discharges of Tacora volcano (northern Chile). J. Volcanol. Geotherm. Res. 208 (3-4), 77-85. 
Cerling, T.E., Brown, F.H., Bowman, J.R., 1985. Low-temperature alteration of volcanic glass: hydration, Na, K, ${ }^{18} \mathrm{O}$ and Ar mobility. Chem. Geol. Isot. Geosci. 52 (3-4), 281-293.

Chiodi, A., 2015. Caracterización geoquímica de Sistemas geotérmicos en dos ambientes contrastados del Noroeste Argentino: Puna Austral y Sistema de Santa Bárbara. Ph.D thesis. Universidad Nacional de Salta, Argentina, pp. 197.

Chiodi, A., Báez, W., Tassi, F., Bustos, E., Viramonte, J.G., Giordano, G., Filipovich, R., Ahumada, Ma.F., 2017. Modelo conceptual preliminar del sistema geotermal de Cerro Blanco (Puna Austral) a partir de estudios de geoquímica de fluidos. In: Proceedings Geological Congress, San Miguel de Tucumán, Argentina. S10. pp. $30-35$.

Chiodini, G., Frondini, F., Marini, L., 1995. Theoretical geothermometers and $\mathrm{PCO}_{2}$ indicators for aqueous solutions coming from hydrothermal systems of medium-low temperature hosted in carbonate-evaporite rocks. Application to the thermal springs of the Etruscan Swell, Italy. Appl. Geochem. 10 (3), 337-346.

Chiodini, G., 1996. Gases dissolved in groundwaters: analytical methods and examples of applications in central Italy. In: Marini, L., Ottonello, G. (Eds.), Rome Seminar on Environmental Geochemistry. Pacini Editore, Castelnuovo d Porto, Rome (Italy), pp. 135-148.

D'Amore, F., Panichi, C., 1980. Evaluation of deep temperatures of hydrothermal systems by a new gas geothermometer. Geochem. Cosmochim. Acta 44, 549-556.

Di Filippo, M., Di Nezza, M., Colombi, A., Viramonte, J.G., Toro, B., 2008. Estructura gravimétrica del Complejo Volcánico Cerro Blanco, Puna Austral, Argentina. In: Proceedings Geological Congress, Jujuy, Argentina, vol. 1. pp. 203-204.

Doveri, M., Lelli, M., Marini, L., Raco, B., 2010. Revision, calibration, and application of the volume method to evaluate the geothermal potential of some recent volcanic areas of Latium, Italy. Geothermics 39, 260-269. https://doi.org/10.1016/j. geothermics.2010.06.002.

Ducea, M.N., Seclaman, A.C., Murray, K.E., Jianu, D., Schoenbohm, L.M., 2013. Mantledrip magmatism beneath the Altiplano-Puna plateau, central Andes. Geology 41 (8), 915-918.

Ellis, A.J., Mahon, W.A.J., 1964. Natural hydrothermal systems and experimental hot water/rock interactions. Geochem. Cosmochim. Acta 28, 1323-1357.

Ellis, A.J., Mahon, W.A.J., 1967. Natural hydrothermal systems and experimental hot water/rock interactions (part II). Geochem. Cosmochim. Acta 31, 519-538.

Evans, W., White, L., Rapp, J., 1998. Geochemistry of some gases in hydrothermal fluids from the southern Juan de Fuca Ridge. J. Geophys. Res. 15, 305-313.

Fernández-Turiel, J.L., Perez-Torrado, F.J., Rodríguez González, A., Saavedra, J., Carracedo, J.C., Rejas, M., Lobo, A., Osterrieth, M., Carrizo, J., Esteban, G., Gallardo, J., Ratto, N., 2019. The large eruption $4.2 \mathrm{ka}$ cal BP in Cerro Blanco, central volcanic zone, Andes: insights to the Holocene eruptive deposits in the southern Puna and adjacent regions. Estud. Geol. 75 (1), e088.

Filipovich, R., Barrios, A., Ahumada, Ma.F., Chiodi, A., Báez, W., Giordano, G., Viramonte, J.G., 2017. Probabilistic assessment of electrical potential of Tocomar Geothermal field (Central Puna-NW Argentina) using volumetric method. In: Proceedings 39th Geothermal Workshop, Roturua, New Zealand, pp. 84-88.

Fiorella, R.P., Poulsen, C.J., Zolá, R.S.P., Jeffery, M.L., Ehlers, T.A., 2015. Modern and long-term evaporation of central Andes surface waters suggests paleo archives underestimate Neogene elevations. Earth Planet. Sci. Lett. 432, 59-72.

Fischer, T.P., Chiodini, G., 2015. Volcanic, magmatic and hydrothermal gases. In: Sigurdsson, H. (Ed.), Encyclopedia of Volcanoes. Academic Press.,pp. 779-797.

Fournier, R.O., 1973. Silica in thermal waters. Laboratory and field investigations. In: International Symposium on Hydrogeochemistry and Biochemistry, Tokyo, vol. 1. pp. 132-139.

Fournier, R.O., 1991. Water geothermometers applied to geothermal energy. In: Application of Geochemistry in Geothermal Reservoir Development. UNITAR, Nueva York, pp. 37-65.

Gat, J., 1996. Oxygen and hydrogen isotopes in the hydrologic cycle. Annu. Rev. Earth Planet Sci. 24, 225-262.

Giggenbach, W.F., 1987. Redox processes governing the chemistry of fumarolic gas dis charges from White Island, New Zeland. Appl. Geochem. 2, 143-161.

Giggenbach, W.F., 1988. Geothermal solute equilibria. Geochem. Cosmochim. Acta 52, 2749-2765.

Giggenbach, W.F., 1991. Chemical techniques in geothermal exploration. In: Application of Geochemistry in Geothermal Reservoir Development. UNITAR, Nueva York, pp. 253-273.

Giggenbach, W.F., 1992. The composition of gases in geothermal and volcanic systems as a function of tectonic setting. In: Kharaka, Y.K., Maest, A.S. (Eds.), Water-Rock Interaction. Balkema, Rotterdam, pp. 873-878.

Giggenbach, W.F., 1995. Variations in the chemical and isotopic composition of fluids discharged over the Taupo Volcanic Zone. J. Volcanol. Geotherm. Res. 68, 89-116.

Giggenbach, W.F., 1997a. The origin and evolution of fluids in magmatic-hydrotherma systems. In: Barnes, H.L. (Ed.), Geochemistry of Hydrothermal Ore Deposits. John Wiley and Sons, New York, pp. 737-789.

Giggenbach, W.F., 1997b. Relative importance of thermodynamic and kinetic processes in governing the chemical and isotopic composition of carbon gases in high-heatflow sedimentary basins. Geochem. Cosmochim. Acta 61, 3763-3785.

Giggenbach, W.F., Goguel, R., 1989. Collection and Analysis of Geothermal and Volcanic Water and Gas Discharges, Unpublished Report. Chemistry Division. Department of Scientific and Industrial Research, Petone, New Zealand, pp. 81.

Giggenbach, W.F., Poreda, R.J., 1993. Helium isotopic and chemical composition of gases from volcanic-hydrothermal systems in the Philippines. Geothermics 22 (5-6), 369-380.

Gilfillan, S.M.V., Sherwood Lollar, B., Holland, G., Blagburn, D., Stevens, S., Schoell, M., Cassidy, M., Ding, Z., Lacrampe-Couloume, G., Ballentine, C.J., 2009. Solubility trapping in formation water as dominant CO2 sink in natural gas fields. Nature 458,
$614-618$.

Giordano, G., Pinton, A., Cianfarra, P., Baez, W., Chiodi, A., Viramonte, J., Norini, G., Groppelli, G., 2013. Structural control on geotermal circulation in the Cerro Tuzgle-Tocomar geothermal volcanic area (Puna plateau, Argentina). J. Volcanol. Geotherm. Res. 249, 77-94.

Giordano, G., De Benedetti, A.A., Bonamico, A., Ramazzotti, P., Mattei, M., 2014. Incorporating surface indicators of reservoir permeability into reservoir volume calculations: application to the Colli Albani caldera and the Central Italy Geothermal Province. Earth Sci. Rev. 128, 75-92.

Giordano, G., Ahumada, F., Aldega, L., Báez, W., Becchio, R., Bigi, S., Caricchi, C., Chiodi, A., Corrado, S., De Benedetti, A.A., Favetto, A., Filipovich, R., Fusari, A., Gropelli, G., Invernizzi, C., Mafucci, R., Norini, G., Pinton, A., Pomposiello, C., Tassi, F., Taviani, S., Viramonte, J.G., 2016. Preliminary data on the structure and potential of the Tocomar geotermal field (Puna plateau, Argentina). Energy Procedia 97, 202-209.

Göb, S., Loges, A., Nolde, N., Bau, M., Jacob, D.E., Markl, G., 2013. Major and trace element compositions (including REE) of mineral, thermal, mine and surface waters in SW Germany and implications for water-rock interaction. Appl. Geochem. 33, $127-152$.

Goff, F., Janik, C.J., 2000. Geothermal systems. In: Ballard, R. (Ed.), Encyclopedia of Volcanoes. Academic Press., pp. 1415.

Gonfiantini, R., Roche, M.A., Olivry, J.C., Fontes, J.C., Zuppi, G.M., 2001. The altitude affect on the isotopic composition of tropical rains. Chem. Geol. 181, 147-167.

Heit, B., Bianchi, M., Yuan, X., Kay, S.M., Sandvol, E., Kumar, P., Kind, R., Alonso, R., Brown, L., Comte, D., 2014. Structure of the crust and the lithosphere beneath the southern Puna plateau from teleseismic receiver functions. Earth Planet. Sci. Lett. $385,1-11$.

Henderson, S., Pritchard, M.E., 2013. Decadal volcanic deformation in the Central Andes Volcanic Zone revealed by InSAR time series. Geochem. Geophys. Geosyst. 14, 1358-1374.

Hilton, D.R., Hammerschmidt, K., Teufel, S., Friedrichsen, H., 1993. Helium isotope characteristics of Andean geothermal fluids and lavas. Earth Planet. Sci. Lett. 120 (3-4), 265-282.

Hilton, D.R., Fischer, T.P., Marty, B., 2002. Noble gases and volatile recycling at subduction zones. In: Porcelli, D., Ballentine, C.J., Wieler, R. (Eds.), Noble Gases in Cosmochemistry and Geochemistry. Mineralogical Society of America, Washington, pp. 319-370.

Hoefs, J., 1997. Stable Isotope Geochemistry, fourth ed. Springer-Verlag, Berlin, Germany, pp. 201.

Hoefs, J., 2008. Stable Isotope Chemistry. Springer, Berlin, New York, pp. 260.

Hoke, L., Hilton, D.R., Lamb, S.H., Hammerschmidt, K., Friedrichsen, H., 1994. 3He evidence for a wide zone of active mantle melting beneath the Central Andes. Earth Planet. Sci. Lett. 128, 341-355.

Hurwitz, S., Kipp, K.L., Ingebritsen, S.E., Reid, M.E., 2003. Groundwater flow, heat transport, and water table position within volcanic edifices: implications for volcanic processes in the Cascade Range. J. Geophys. Res. Solid Earth 108 (B12), 2557. https://doi.org/10.1029/2003JB002565.

Hurwitz, S., Christiansen, L.B., Hsieh, P.A., 2007. Hydrothermal fluid flow and deformation in large calderas: inferences from numerical simulations. J. Geophys. Res. Solid Earth 112 (B2). https://doi.org/10.1029/2006JB004689.

Inguaggiato, S., Pecoraino, G., D'Amore, F., 2000. Chemical and isotopical characterisation of fluid manifestations of Ischia Island (Italy). J. Volcanol. Geotherm. Res. 99, 151-178.

Inguaggiato, S., Rizzo, A., 2004. Dissolved helium isotope ratios in ground-waters: a new technique based on gas-water re-equilibration and its application to Stromboli volcanic system. Appl. Geochem. 19 (5), 665-673.

Kaasalainen, H., Stefánsson, A., 2012. The chemistry of trace elements in surface geotermal waters and steam, Iceland. Chem. Geol. 330, 60-85.

Kay, S.M., Coira, B., Wörner, G., Kay, R.W., Singer, B.S., 2011. Geochemical, isotopic and single crystal 40Ar/39Ar age constraints on the evolution of the Cerro Galán ignimbrites. Bull. Volcanol. 73 (10), 1487-1511.

Kharaka, Y.K., Mariner, R.H., 1989. Chemical geothermometers and their application to formation waters from sedimentary basins. In: Naeser, N.D., McCollon, T.H. (Eds.), Thermal History of Sedimentary Basins. Springer, New York, pp. 99-117.

Langelier, W.F., Ludwig, H.F., 1942. Graphical methods for indicating the mineral caracter of natural waters. J. AWWA (Am. Water Works Assoc.) 34, 335.

López, J.F., 2016. Evolución de la deformación en el Complejo Volcánico Cerro Blanco (Puna Austral) utilizando imágenes satelitales ópticas, radar y datos geodésicos. Ph.D. thesis. Universidad Nacional de Salta, Argentina, pp. 220.

Mamyrin, B., Tolstikhin, I., 1984. Helium isotopes in nature. In: Fyfe, W. (Ed.), Development in Geochemistry. Elsevier, Amsterdam, pp. 288.

Marty, B., Jambon, A., 1987. C3He in volatile fluxes from the solid Earth: implications for carbon geodynamics. Earth Planet. Sci. Lett. 83 (1-4), 16-26.

Matsuo, S., Suzuki, J., Mitzutani, Y., 1978. Nitrogen to argon ratio in volcanic gases. In: Alexander, E.C., Ozima, M. (Eds.), Terrestrial Rare Gases. Japan Science Society Press, Tokyo, pp. 17-25.

McCoy-West, A.J., Milicich, S., Robinson, T., Bignall, G., Harvey, C.C., 2011. Geothermal resources in the Pacific Islands: the potential of power generation to benefit indigenous communities. In: Proceedings of the Thirty-Sixth Workshop on Geothermal Reservoir Engineering. Stanford, California, 2:SGP-TR-191.

Moeck, I.S., 2014. Catalog of geothermal play types based on geologic controls. Renew. Sustain. Energy Rev. 37, 867-882.

Montero López, C., Hongn, F., Seggiaro, R., Marrett, R., Ratto, N., 2009. Relación entre el volcanismo y los registros arqueológicos en el bolsón de Fiambalá. In: Ratto, N. (Ed.), Entrelazando ciencias, sociedad y ambiente antes de la conquista española. Buenos Aires, Argentina, pp. 131-156.

Montero López, C., Hongn, F., Brod, J., Seggiaro, R., Marrett, R., Sudo, M., 2010. 
Magmatismo ácido del Mioceno Superior-Cuaternario en el área de Cerro Blanco-La Hoyada, Puna Sur. Rev. Asoc. Geol. Argent. 67, 329-348.

Mors, R.A., Gomez, F., Astini, R., 2016. Travertinos y tufas de la Terma Los Hornos, Puna de Catamarca, Argentina: principales controles en el desarrollo de texturas y fábricas. Argentine sedimentology meeting, La Pampa, Argentina, pp. 120.

Marrett, R., Emerman, S.H., 1992. The relations between faulting and mafic magmatism in the Altiplano-Puna plateau (central Andes). Earth Planet. Sci. Lett. 112 (1-4), 53-59.

Muffler, P., Cataldi, R., 1978. Methods for regional assessment of geothermal resources. Geothermics 7, 53-89.

Nicholson, K., 1993. Geothermal Fluids: Chemistry and Exploration Techniques. SpringerVerlag, Berlin, pp. 268.

Norini, G., Cogliati, S., Báez, W., Arnosio, M., Bustos, E., Viramonte, J.G., Groppelli, G., 2014. The geological and structural evolution of the Cerro Tuzgle Quaternary stratovolcano in the back-arc region of the Central Andes, Argentina. J. Volcanol. Geotherm. Res. 285, 214-228.

Ohmoto, H., Goldhaber, M.B., 1997. Sulfur and carbon isotopes. In: Barnes, H.L. (Ed.), Geochemistry of Hydrothermal Ore Deposits. John Wiley \& Sons, pp. 517-611.

Parkhurst, D.L., Appelo, C.A.J., 1999. User's guide to PHREEQC (version 2)-a computer program for speciation, batch-reaction, one-dimensional transport, and inverse geochemical calculations. U.S. Geol. Surv. Water Resour. Investig. Rep. 99-4259, 312.

Peralta Arnold, Y., Cabassi, J., Tassi, F., Caffe, P., Vaselli, O., 2017. Fluid geochemistry of deep-seated geotermal resource in the Puna plateau (jujuy Province, Argentina). J. Volcanol. Geotherm. Res. 338, 121-134.

Poreda, R., Craig, H., 1989a. Helium isotope ratios in circum-Pacific volcanic arcs. Nature 338, 473-478.

Poreda, R.J., Craig, H., 1989b. Helium isotope ratios in circum-Pacific volcanic arcs. Nature 338, 473-478.

Ricci, H.I., Valladares Carrillo, H., Pezzutti, N., Godeas, M., Segal, S.J., 1999. Distrito Minero La Hoyada, Catamarca. In: In: Zappettini, O. (Ed.), Recursos Minerales de la República Argentina, vol. 35. Instituto de Geología y Recursos Minerales SEGEMAR, Buenos Aires, Argentina, pp. 1627-1636.

Rollinson, H., 1993. Using Geochemical Data. Longman, London, UK, pp. 352.

Sano, Y., Marty, B., 1995. Origin of carbon in fumarolic gases from island arcs. Chem. Geol. 119, 265-274. https://doi.org/10.1016/0009-2541 (94)00097-R.

Sano, Y., Naoto, T., Nishio, Y., Fischer, T.P., Williams, S.N., 2001. Volcanic flux of nitrogen from the Earth. Chem. Geol. 171, 263-271.

Schoenbohm, L.M., Strecker, M.R., 2009. Normal faulting along the southern margin of the Puna Plateau, northwest Argentina. Tectonics 28 (5).

Seggiaro, R., Hongn, F., Folguera, A., Clavero, J., 2000. Hoja Geologica 2769- II, Paso de San Francisco, 1:250.000: Buenos Aires, Servicio Geológico Minero Argentino. Programa Nacional de Cartas Geologicas, 1 Map.

Snyder, G., Poreda, R., Fehn, U., Hunt, A., 2003. Sources of nitrogen and methane in Central American geothermal settings: noble gas and 129I evidence for crustal and magmatic volatile components. Geochem. Geophys. Geosyst. 4, 1-28.

Sorey, M.L., Suemnicht, G.A., Sturchio, N.C., Nordquist, G.A., 1991. New evidence on the hydrothermal system in Long Valley caldera, California, from wells, fluid sampling, electrical geophysics, and age determinations of hot-spring deposits. J. Volcanol.
Geotherm. Res. 48, 229-263.

Stewart, M.K., 1975. Stable isotope fractionation due to evaporation and isotopic exchange of falling waterdrops: applications to atmospheric processes and evaporation of lakes. J. Geophys. Res. 80, 1133-1146.

Stimac, J., Goff, F., Goff, C., 2015. Intrusion-Related geotermal systems. In: Sigurdsson, H. (Ed.), Encyclopedia of Volcanoes. Academic Press., pp. 799-822.

Tchilinguirian, P., Olivera, D.E., 2014. Late quaternary paleoenvironments, South andean Puna $\left(25^{\circ}-27^{\circ} \mathrm{S}\right)$, Argentina. In: In: Pintar, Lizzy (Ed.), Hunter-gatherers from a HighElevation Desert. People of the Salt Puna (Northwest Argentina) BAR International Series 1524, vol. 2641. British Archaeological Reports, Oxford, pp. 43-70.

Tassi, F., Aguilera, F., Darrah, T., Vaselli, O., Capaccioni, B., Poreda, R.J., Huertas, A.D., 2010. Fluid geochemistry of hydrothermal systems in the Arica-Parinacota, Tarapacá and Antofagasta regions (northern Chile). J. Volcanol. Geotherm. Res. 192 (1-2), $1-15$.

Todesco, M., Giordano, G., 2010. Modelling of $\mathrm{CO}_{2}$ circulation in the Colli Albani area. In: In: Funiciello, R., Giordano, G. (Eds.), The Colli Albani Volcano, vol. 3. Geological Society, London, Special Publications of IAVCEI, pp. 311-328.

Valero-Garcés, B., Delgado-Huertas, A., Ratto, N., Navas, A., 1999. Large 13C enrichment in primary carbonates from Andean Altiplano lakes, northwest Argentina. Earth Planet. Sci. Lett. 171, 253-266.

Vaselli, O., Tassi, F., Montegrossi, G., Capaccioni, B., Giannini, L., 2006. Sampling and analysis of volcanic gases. Acta Volcanologica 18, 65-76.

Viramonte, J.G., Castro Godoy, S., Arnosio, M., Becchio, R., Poodts, M., 2005a. El Campo Geotermal de la Caldera de Cerro Blanco, Utilización de Imágenes Aster. Proceedings Geological Congress, La Plata, Argentina, pp. 505-512.

Viramonte, J.G., Arnosio, M., Becchio, R., Gropelli, G., Norini, G., Corazzatto, C., DiFillipo, M., Blanco, M., Eulillades, P., Poodts, M., Castro Godoy, S., Klotz, J., Asch, G., Heit, B., 2005b. Cerro Blanco Volcanic Complex: the Youngest Caldera System in the Southern Central Andes. A Multidisciplinary Earth Science Project. Colloquium on Latin American Geosciences, Potsdam, pp. 135.

Viramonte, J.G., Arnosio, M., Becchio, R., de Silva, S., Roberge, J., 2008. Cerro Blanco volcanic complex, Argentina: a late Pleistocene to Holocene rhyolitic arc-related caldera complex in the central Andes. IAVCEI, General assembly Reykjavík, Islandia 1.

Wilson, N., Webster-Brown, J., Brown, K., 2012. The behaviour of antimony released from surface geothermal features in New Zealand. J. Volcanol. Geotherm. Res. 247, 158-167.

Whitfield, M., 1978. Activity coefficients in natural waters. In: Pytkowicz, R.M. (Ed.), Activity Coefficients in Electrolyte Solutions. CRC Press, Boca Raton, Florida, pp. 153-300.

Wood, C.P., 1995. Calderas and geothermal systems in the Taupo volcanic zone, New Zealand. In: Proceedings World Geothermal Congress, Florence, pp. 1331-1336.

Zarrouk, S., Simiyu, F., 2013. A review of geothermal resource estimation methodology. In: 35th New Zealand Geothermal Workshop. Rotorua. International Geothermal Association, New Zealand, pp. 8.

Zhang, J., Quay, P.D., Wilbur, D.O., 1995. Carbon isotope fractionation during gas-water Exchange and dissolution of CO2. Geochem. Cosmochim. Acta 59, 107-114. 